\title{
Copper Homeostasis in Mammals, with Emphasis on Secretion and Excretion. A Review
}

\author{
Maria C. Linder \\ Department of Chemistry and Biochemistry, California State University, Fullerton, CA 91831, USA; \\ mlinder@fullerton.edu
}

Received: 9 June 2020; Accepted: 7 July 2020; Published: 13 July 2020

\begin{abstract}
One of the hallmarks of Cu metabolism in mammals is that tissue and fluid levels are normally maintained within a very narrow range of concentrations. This results from the ability of the organism to respond to variations in intake from food and drink by balancing excretion, which occurs mainly via the bile and feces. Although this sounds straightforward and we have already learned a great deal about aspects of this process, the balance between overall intake and excretion occurs over a high background of $\mathrm{Cu}$ recycling, which has generally been ignored. In fact, most of the $\mathrm{Cu}$ absorbed from the GI tract actually comes from digestive fluids and is constantly "re-used". A great deal more recycling of $\mathrm{Cu}$ probably occurs in the interior, between cells of individual tissues and the fluid of the blood and interstitium. This review presents what is known that is pertinent to understanding these complexities of mammalian $\mathrm{Cu}$ homeostasis and indicates where further studies are needed.
\end{abstract}

Keywords: copper; secretion; excretion; liver; kidney; bile; saliva; gastric fluid; pancreatic fluid; urine; ceruloplasmin; ATP7A; ATP7B; small copper carriers

\section{Introduction}

The term "homeostasis", or the maintenance of constancy within an organism, aptly applies to Cu in mammals. The constancy of tissue and fluid concentrations of this trace metal is truly remarkable, and not only so within the same species but across almost all mammals (with the exception of the $\operatorname{dog}$ and perhaps some others as yet not identified). Liver concentrations are usually about $5 \mu \mathrm{g} / \mathrm{g}$; heart concentrations are also about $5 \mu \mathrm{g} / \mathrm{g}$; brain concentrations are $4-5 \mu \mathrm{g} / \mathrm{g}$; muscle concentrations are $\sim 1 \mu \mathrm{g} / \mathrm{g}$, and so on [1]. Kidney concentrations are more variable, at around $4-12 \mu \mathrm{g} / \mathrm{g}$. It is also remarkable how robustly mammals can respond to receiving an excess of $\mathrm{Cu}$. In the case of mice, for example, loaded with three times their normal total amounts of body $\mathrm{Cu}$, concentrations of this element in the organs and fluids virtually returned to normal after about 2 weeks [2] (Figure 1). It is well understood that the liver plays a major role in remediating this and other kinds of $\mathrm{Cu}$ overload by transferring excess $\mathrm{Cu}$ to the bile, which then returns it to the gut for fecal excretion. Indeed, it is generally assumed that this is the way mammalian $\mathrm{Cu}$ homeostasis is regulated. This idea is based mainly on the findings from the most well-studied disease of $\mathrm{Cu}$ overload (Wilson disease), first identified in humans and involving the "Cu pump" ATP7B [3,4], and on findings for Cu overload in dogs involving other proteins required for putting $\mathrm{Cu}$ into bile, namely COMMD1 [5,6] and ABCA12 [7]. Moreover, it has long been known that very little copper is excreted through the urine (on the order of $50 \mu \mathrm{g} /$ day). What has generally been ignored, however, is that a considerable amount of $\mathrm{Cu}$ is secreted into the gastrointestinal tract daily, beyond that contributed by bile and the diet. This $\mathrm{Cu}$ (from saliva, gastric, pancreatic and intestinal juices) is of course largely recycled (meaning re-absorbed, re-distributed and re-secreted). How that all happens, and its implications for understanding $\mathrm{Cu}$ homeostasis, has not particularly been considered. This review addresses current knowledge about 
these and other aspects of $\mathrm{Cu}$ metabolism that affect homeostasis, and highlights where additional studies are needed to better understand this process.

\section{Secretion and Recycling of $\mathrm{Cu}$ in Gastrointestinal Fluids}

The average $70 \mathrm{~kg}$ human adult has a total of about $110 \mathrm{mg}$ of $\mathrm{Cu}$ in the body [8]. Dietary intake is about $1 \mathrm{mg}$ per day [9]. Along with food and drink, many liters of secreted fluids enter the digestive tract daily, averaging roughly $1-2 \mathrm{~L}$ for saliva, with $2.5 \mathrm{~L}$ of gastric fluid, $1.5 \mathrm{~L}$ of pancreatic fluid, 0.5-0.75 L of bile, and unknown volumes of intestinal fluids, for the average $70 \mathrm{~kg}$ adult [1]. Each of these fluids contain $\mathrm{Cu}$ (Table 1). Multiplying concentration by volume indicates that more $\mathrm{Cu}$ comes into the GI tract through these secretions than comes in from outside (Table 1). About one milligram comes from saliva, the stomach and pancreas; $0.6-6 \mathrm{mg}$ are added by the bile, totaling from 1.6 to $7 \mathrm{mg}$ per day not coming from food and drink. Balance studies as well as those using radioactive or stable $\mathrm{Cu}$ isotopes indicate that in humans, $50-80$ percent of $\mathrm{Cu}$ in the GI tract is absorbed [10]. Absorption occurs primarily (and probably exclusively) in the small intestine. This means that much more $\mathrm{Cu}$ is entering enterocytes than that in the diet. Since homeostasis is the balance between intake and output, this needs to be taken into account, and what happens to the non-dietary portion needs to be included.
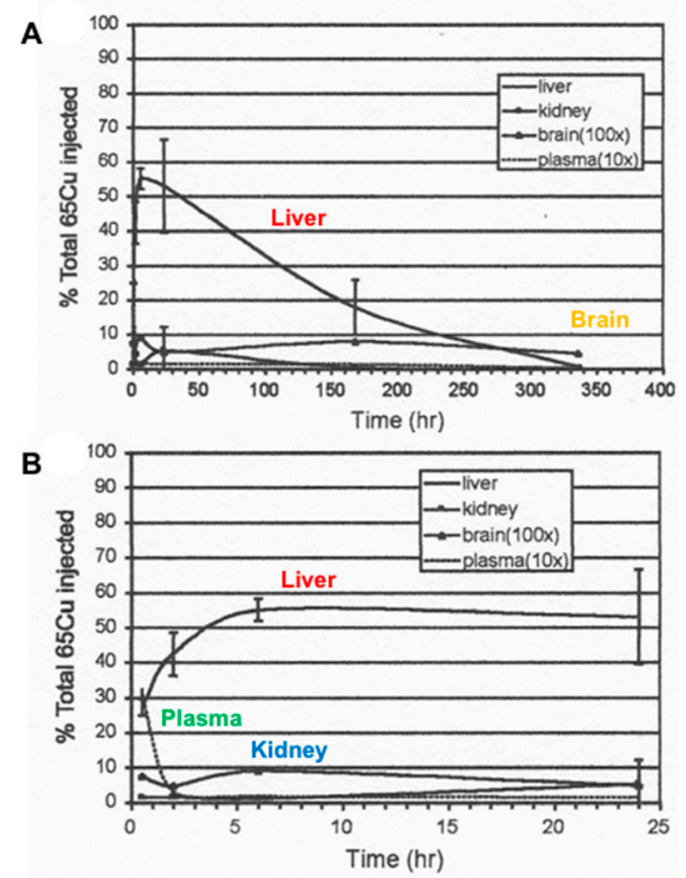

Figure 1. Time course of loss (A) and incorporation (B) of excess extrinsic ${ }^{65} \mathrm{Cu}$ from mouse organs after the injection of this stable isotope. Mice were preloaded with 3 times more $\mathrm{Cu}$ than the total estimated to be in their bodies, over $14 \mathrm{~h}$, after which they were sacrificed at various times, as indicated, and the percent dose was determined. Data for plasma and brain were multiplied 10x and 100x, respectively, to make them visible. Annotated, and reprinted with permission from Springer, Biometals, Copper binding components of blood plasma and organs and their response to influx of.

Almost all of the $\mathrm{Cu}$ absorbed by the small intestine enters the hepatic portal vein and thus the liver. Tracer studies in humans and rodents indicated that most of it initially enters the cells of this organ $[1,10,14,15]$ (see example in Figure 2). Assuming that the tracer is assimilated in the same way as other $\mathrm{Cu}$ ions entering the gut, enterocytes and blood, this means that most of the recycled $\mathrm{Cu}$ (coming from GI secretions) also initially goes into liver cells. In hepatocytes, the three main things we know happen to the incoming copper are (a) entry of some of it into endogenous Cu-dependent proteins; (b) incorporation of a significant portion into ceruloplasmin, for secretion into the blood; and (c) 
incorporation of excess into the bile to maintain homeostasis through excretion. All of this results in a net daily excretion of about $1 \mathrm{mg} \mathrm{Cu}$ in the feces, balancing the $\sim 1 \mathrm{mg} \mathrm{Cu}$ taken in through food and drink.

Table 1. Copper in Fluids of the Human Gastrointestinal Tract and Urine *.

\begin{tabular}{ccccc}
\hline Fluid & $\begin{array}{c}{[\mathbf{C u}]} \\
\mathbf{m g} / \mathbf{L}\end{array}$ & $\mathbf{( u M )}$ & $\begin{array}{c}\text { Volume } \\
(\mathbf{L} / \mathbf{d a y})\end{array}$ & $\begin{array}{c}\text { Total Cu } \\
(\mathbf{m g})\end{array}$ \\
\hline Saliva & 0.1 & 1.6 & $1-2$ & 0.15 \\
\hline Gastric juice & 0.08 & 1.2 & 2.5 & 0.18 \\
\hline Pancreatic juice & 0.3 & 4 & 1.5 & 0.5 \\
\hline Bile & $4 \pm 2$ & $19-63$ & $0.5-0.75$ & $0.6-6$ \\
\hline Duodenal fluid & 0.016 & & $(1 ?)$ & 0.016 \\
\hline Urine & $(0.02-0.1)^{* *}$ & $(0.03-0.10)$ & 1.5 & $0.04-0.05^{* * *}$ \\
\hline
\end{tabular}

* Updated from Table 1-5, Biochemistry of Copper, Linder, 1991 [1]; ** calculated based on the Total Cu values and average urinary volume; ${ }^{* * *}$ solid values obtained in past and recent studies [11-13].

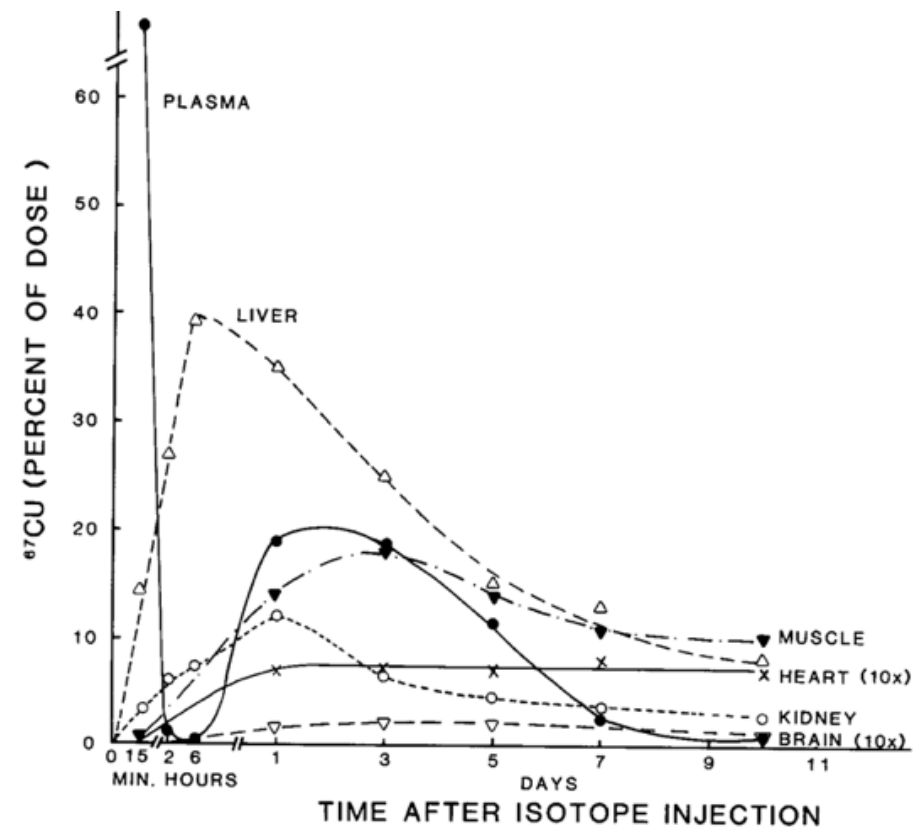

Figure 2. Distribution of ${ }^{67} \mathrm{Cu}$ in rat organs and blood plasma at various times after tracer administration. Data for each time point are mean values for mostly $5-7$ rats, given as $\%$ of ${ }^{67} \mathrm{Cu}$ dose. Data for brain and heart have been multiplied $10 \times$ to make them more visible. Reprinted with permission from reference Weiss, K.C.; et al. [14].

Clearly, a great deal of $\mathrm{Cu}$ enters the GI tract in secretions and is recycled. However, not all secretions are recycled equally. Existing data indicate that the $\mathrm{Cu}$ in bile is not only more tightly bound to biliary components, but is less re-absorbable than that in other GI fluids (Table 2). The amounts of $\mathrm{Cu}$ secreted into the bile are also highly variable among human individuals (Table 1). These characteristics of bile are consistent with a role in maintaining the constancy of $\mathrm{Cu}$ levels within the organism through the adjustment of the amounts and forms of $\mathrm{Cu}$ secreted into bile that contribute to fecal excretion. The regulation of $\mathrm{Cu}$ homeostasis is thus primarily through biliary excretion rather than changes in the degree of absorption, so much $\mathrm{Cu}$ is re-absorbed and recycled from the GI tract, and excretion adapts to how much needs to be retained. 
Table 2. Absorption and Dialysability of $\mathrm{Cu}$ in GI Tract Fluids of Rats *.

\begin{tabular}{|c|c|c|c|}
\hline Fluid & $\begin{array}{l}\text { Dialysable Cu } \\
\left.\text { (Percent }{ }^{64} \mathrm{Cu}\right)\end{array}$ & $\begin{array}{c}\text { Intestinal Absorption } \\
\text { (Percent) }\end{array}$ & $\begin{array}{l}\text { Body retention } \\
\left.\text { (Percent }{ }^{64} \mathrm{Cu}\right)\end{array}$ \\
\hline \multicolumn{4}{|l|}{ In vitro ${ }^{64} \mathrm{Cu}$ labeled ${ }^{a}$} \\
\hline Saliva & $98 \pm 2(6)$ & & $13 \pm 3(6)$ \\
\hline Gastric juice & $97 \pm 2(6)$ & & $12 \pm 10(6)$ \\
\hline Bile (gall bladder) & $12 \pm 12(5)$ & & $6 \pm 1(6)$ \\
\hline \multicolumn{4}{|l|}{ In vivo ${ }^{64} \mathrm{Cu}$-labeled ${ }^{\mathrm{b}}$} \\
\hline \multicolumn{4}{|l|}{ Time after intubation } \\
\hline Bile $0-4 \mathrm{~h}$ & $50 \pm 7(9)$ & $16 \pm 3(8)$ & \\
\hline $4-8 \mathrm{~h}$ & $28 \pm 6(9)$ & $13 \pm 4(8)$ & \\
\hline $8-24 \mathrm{~h}$ & $16 \pm 3(9)$ & $10 \pm 3(4)$ & \\
\hline
\end{tabular}

\section{Biliary Cu Excretion}

The importance of the biliary route for $\mathrm{Cu}$ excretion is clearly demonstrated by what happens when this route is compromised, notably when proteins associated with mediating steps in the process of ferrying $\mathrm{Cu}$ into bile are defective, and/or if the common bile duct is ligated, as in experimental animals. Wilson disease, in which a Cu "pump" (ATP7B) in hepatocytes is dysfunctional, results in accumulations of large amounts of $\mathrm{Cu}$ in the liver that eventually lead to hepatic $\mathrm{Cu}$ overload as well as excess accumulation in some other tissues, such as the brain $[3,4,16]$. This is lethal if untreated. As shown in rats, ligating the bile duct results in a marked decrease in the rate of loss of whole-body $\mathrm{Cu}$. Figure 3 shows the loss in normal rats preloaded with ${ }^{67} \mathrm{Cu}$ and monitored for 7 days [2]. Rates of loss of a faster and slower component or route are evident, with the half-life of the faster one being $54 \mathrm{~h}$ (Table 3 ). This rate of $\mathrm{Cu}$ loss was cut in half by ligation ( $\mathrm{t}_{1 / 2}$ going to $117 \mathrm{~h}$ ). Biliary $\mathrm{Cu}$ secretion is very responsive to $\mathrm{Cu}$ treatment. Long-Evans Agouti rats, for example, increased biliary $\mathrm{Cu}$ concentrations 2-3 fold within minutes of receiving an injection of Cu-his [17];

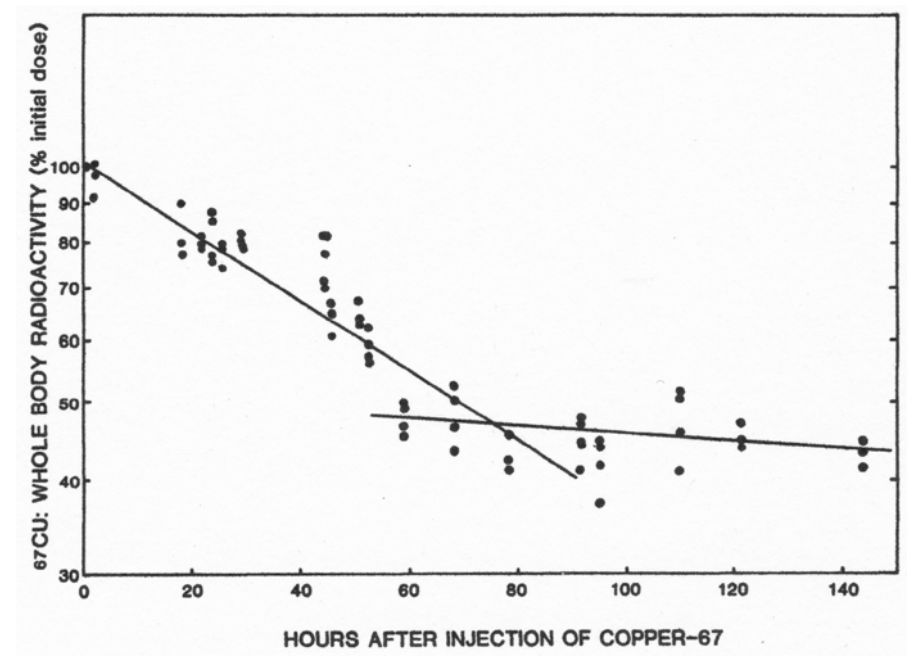

Figure 3. Effect of bile duct ligation on turnover of whole body $\mathrm{Cu}$ in rats. Tabulated data on rates of ${ }^{67} \mathrm{Cu}$ loss in rats where the common bile duct was and was not (sham) ligated prior to ${ }^{67} \mathrm{Cu}$ administration. Reprinted with permission from Linder, M.C. et al. [2]. 
Table 3. Tabulated data on rates of ${ }^{67} \mathrm{Cu}$ loss in rats where the common bile duct was and was not (sham) ligated prior to ${ }^{67} \mathrm{Cu}$ administration. Reprinted with permission from Linder, M.C. et al. [2].

\begin{tabular}{ccc}
\hline & Sham-Operated Controls & Bile Duct Ligation \\
\hline Slope [Means \pm SD (N) $]^{*}$ & $-552 \pm 28(23)$ & $-258 \pm 97(15)^{* *}$ \\
$0-63 \mathrm{~h}$ & $-623 \pm 56(28)$ & $-272 \pm 67(17)^{* * *}$ \\
$0-86 \mathrm{~h}$ & $54 \mathrm{~h}$ & $117 \mathrm{~h}$ \\
\hline Half-life (h) & $49 \mathrm{~h}$ & $110 \mathrm{~h}$ \\
$0-63 \mathrm{~h}$ & & $3.8 \pm 1.1(6)$ \\
$0-86 \mathrm{~h}$ & $4.6 \pm 0.5(6)$ & $105 \pm 42(5)$ \\
\hline $\begin{array}{c}\text { Liver [Means } \pm \mathrm{SD}(\mathrm{N})] \mathrm{Cu}(\mathrm{ug} / \mathrm{g}) \\
{ }^{67} \mathrm{Cu} \text { specific activity (cpm/ug) }\end{array}$ & $64 \pm 11(4)$ & \\
\hline
\end{tabular}

${ }^{*}$ Multiplied by $10^{6} .{ }^{* *} p<0.01,{ }^{* * *} p<0.001$.

Biliary Cu levels of Wistar rats rose eight-fold over $180 \mathrm{~min}$ after the start of continuous intravenous infusion of $\mathrm{CuSO}_{4}$ (318 ng/g body weight/h) [18]. As already mentioned, $\mathrm{Cu}$ concentrations in bile $(\mathrm{mg} / \mathrm{L})$ are also quite variable, with standard deviations for mean values of human bile being on the order of $50 \%(4+2$ [1]; $3.6+1.7$ [19]) (Table 1). Presumably, this reflects adjustments made by hepatocytes in response to different levels of $\mathrm{Cu}$ being absorbed by the intestine and entering the liver.

We are continuing to learn about the mechanisms by which $\mathrm{Cu}$ entering the liver and hepatocytes is forwarded to the bile, particularly with the help of ATP7B (Figure 4). ATP7B functions not only as a means of ridding the body of excess $\mathrm{Cu}$ entering hepatocytes but to supply the metal ion to $\mathrm{Cu}$-dependent proteins that are produced and secreted into the extracellular fluid and blood by hepatocytes and some other cells [20]. In certain cells, such as enterocytes and kidney epithelia, it may also function to sequester/store $\mathrm{Cu}$ in vesicles [21,22]. Hepatocyte ATP7B sits in the membrane of the trans Golgi network (TGN), pumping $\mathrm{Cu}$ from the cytosol into the TGN lumen (Figure 4). Here it encounters apo-ceruloplasmin that has been synthesized in the rough endoplasmic reticulum (ER) and glycosylated in the smooth ER, which then receives the $\mathrm{Cu}$ in the TGN. From there, holo-ceruloplasmin (containing $\mathrm{Cu}$ ) proceeds to the blood (with other secreted proteins) via exocytosis across the "basolateral" portions of the hepatocyte membrane (Figure 4). This is most probably a constant process, with rates of ceruloplasmin synthesis being fairly constant in the liver under normal circumstances [23]. Cu not needed for incorporation into ceruloplasmin and other proteins (including endogenous ones like SOD1 and cytochrome c oxidase) appears to be trafficked (with ATP7B) from the TGN into late endosomes/lysosomes (the endolysosomal compartment) [24]. More importantly, when large amounts of excess $\mathrm{Cu}$ enter hepatocytes, endolysosomal vesicles with ATP7B traffic it towards the bile canalicular ("apical") portions of the hepatocyte membrane, and appear to fuse with it (Figure 4, left side). This would release the $\mathrm{Cu}$ that is inside the vesicles into bile canaliculi, while also bringing ATP7B itself to the apical membrane to directly pump excess $\mathrm{Cu}$ from cytosolic ATOX1 into the developing bile. The hepatocyte apical-targeting sequence, FAFDNVGYE, is near the N-terminus of ATP7B.) These processes are summarized in Figure 4. (For further details, please see reviews by Polishchuk and Lutsenko [25], and Polishchuk and Polishchuk [26], as well as Stewart et al. [27].)

When levels of excess $\mathrm{Cu}$ in the hepatocyte subside, ATP7B recycles back into the TGN, via a clathrin-dependent endocytic process (Figure 4). This depends on a leucine triad located in the C-terminal portion of the ATP7B that is recognized by adaptins [27]. Another protein (COMMD1, formerly MURR1) is also necessary for biliary $\mathrm{Cu}$ excretion, as first demonstrated in Bedlington terriers suffering from liver $\mathrm{Cu}$ toxicosis $[5,28]$. COMMD1 was the first member of what is now recognized as a family of ten proteins involved in endosomal sorting, and also plays a role in endosomal recycling [27]. As a complex with two other proteins (CCDC22-CCDC93), it binds to ATP7B in early endosomes, and somehow assists its return to the TGN [26] (Figure 4). In its various locations (TGN, vesicles, plasma membrane), $\mathrm{Cu}$ is provided to ATP7B by the cytosolic $\mathrm{Cu}$ chaperone, ATOX1 (HAH1). A third 
protein (ABCA12) involved in ferrying $\mathrm{Cu}$ to the bile has also been identified in Bedlington terriers [7]. Although its exact role is still unclear, it may be functionally similar to ATP7B.

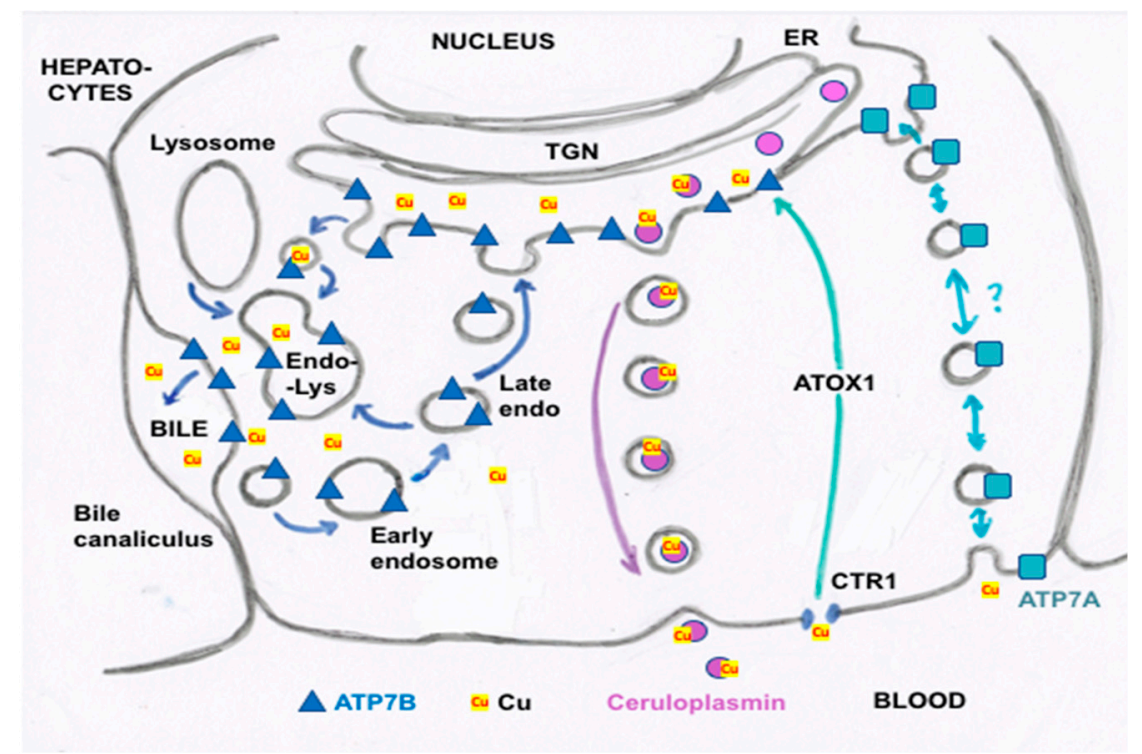

Figure 4. Summary of proposed steps involved in the movement of $\mathrm{cu}$ into bile and secreted by hepatocytes. Based mainly on the data, reviews and figures provided by Polishchuk and Polishchuk [26] and Stewart et al. [27]. Cu ions enter hepatocytes from plasma proteins via copper transporter 1 (CTR1) and at least one other as yet unidentified transporter, and are carried via the chaperone ATOX1 to ATP7B (blue triangles) in the transGolgi network (TGN). In the lumen of the TGN, Cu will be incorporated into apoceruloplasmin (apoCp) (violet circles), forming holoCp, and be released into the blood plasma by exocytosis (center right of the figure) across the "basolateral" hepatocyte membrane. In the absence of excessive $\mathrm{Cu}$ not otherwise incorporated into $\mathrm{Cp}$ and endogenous $\mathrm{Cu}$-dependent proteins and mitochondria, TGN Cu in the lumen will be exported to the bile canaliculi that are formed between hepatocyte apical membranes, leading to the gall bladder and bile duct. This happens through the budding of vesicles from the TGN that contain $\mathrm{Cu}$ and may also contain ATP7B. These fuse with late endosomes also containing ATP7B as well as lysosomes (to form the endo-lysosomal compartment), which then fuses with the apical hepatocyte membrane at a canaliculus (left side of figure). This releases $\mathrm{Cu}$ that was present in the vesicular bodies and also can lead to ATP7B being part of the apical membrane. The latter is particularly important in the presence of excess $\mathrm{Cu}$, which can then flow from ATOX1 directly to ATP7B that pumps it into the bile canaliculi. Small amounts of the Cu efflux "pump", ATP7A (blue squares), are also expressed in hepatocytes (far right of the figure), and may also contribute to $\mathrm{Cu}$ that exits hepatocytes and enters the blood plasma, to bind to proteins like albumin in the exchangeable plasma $\mathrm{Cu}$ pool. Based on what is known in other cells, the much less abundant ATP7A in hepatocytes would either transfer some $\mathrm{Cu}$ in the TGN into secretory vesicles (for exocytosis), and/or traffic it in vesicles to the basolateral membrane to pump $\mathrm{Cu}$ in the cytosol (on ATOX1) into the blood plasma, following which ATP7A would recycle back to the TGN.

Biliary excretion probably varies from minute to minute, as ATP7B and other proteins respond to cytosolic $\mathrm{Cu}$ concentrations in hepatocytes by staying in the TGN or moving to apical portions of the plasma membrane, as previously explained (Figure 4). In general, it is thought that trafficking of existing ATP7B rather than changes in levels of this protein (or that of COMMD1) is responsible for dealing with the day-today routine of sending the right amounts of $\mathrm{Cu}$ out of the liver into the bile to maintain homeostasis [28,29]. Expression of ATP7B is probably quite stable under normal physiological conditions, as also suggested by measurements of mRNA in adult rat liver [23], and relatively little has been done to establish what factors might alter expression and/or rates of synthesis and degradation of ATP7B and COMMD1 in hepatocytes or other cells. However, it has been known for some time that the promoter/enhancer regions of the ATP7B gene contain several metal-responsive elements 
(MREs) [30], to which metal transcription factors (MTFs) could bind. Several reports indicated that large doses of $\mathrm{Cu}$ evoke increased ATP7B expression in the livers of very young animals, such as rat pups [31] and piglets [32], as well as in seabream [33]. The recent work of Stalke et al. [34], which employed a reporter gene construct in HepG2 cells, provided evidence that enhanced ATP7B expression induced by $\mathrm{Cu}$ involves binding of MTF1 to the " $\mathrm{e}$ " MRE in the gene regulatory region. In young fish (guppies), $\mathrm{Cu}$ treatment was found to increase Atp7b (and Ctr1) mRNA expression in the gut and gills but not in the liver [35]. In cultured human skin fibroblasts, small and inconsistent effects of adding $\mathrm{Cu}$ (concentrations unknown) or $\mathrm{Cu}$ chelators on mRNA expression were observed for ATP7B, but there was a more clear-cut positive effect when adding the $\mathrm{Fe}(\mathrm{II})$-chelator, ferrozine, to cause iron deficiency [36]. For suckling and adult rat duodenum, there was a report that protein expression of the ATP7B homolog, ATP7A, was enhanced by iron deficiency, and induced its localization to the brush border/apical rather than basolateral membrane, the latter of which occurs in response to $\mathrm{Cu}$ [37]. However, a multifaceted study of the response of Atp7a to $\mathrm{Cu}$ treatment and deficiency showed that, in cultured intestinal (IEC-6) cells, $\mathrm{Cu}$ induced no immediate changes in mRNA (over $3 \mathrm{~h}$ ) but markedly increased protein expression by decreasing the degradation of Atp7a, relative to $\mathrm{Cu}$ deficiency. Longer term $(12 \mathrm{~h}) \mathrm{Cu}$ treatment of cultured 12 day old mouse liver cells showed large increases in Atp7a over that in $\mathrm{Cu}$ deficiency, with the same being true in human vascular epithelial cells (HUVEC). Seven day old mice treated daily (for three days) with $\mathrm{Cu}$ only demonstrated an increased liver Atp7a protein expression at very high doses, doses that also increased the blood serum levels of $\mathrm{Cu}$ (suggesting toxicity), and there were no effects on levels of Atp7b in the liver [38]. Thus, it seems that in certain conditions, and particularly in the organs of the very young, $\mathrm{Cu}$ and perhaps also Fe have roles in regulating expression of these P-type Cu ATPases.

As concerns COMMD1, its overexpression in HEK 293 cells was shown to enhance degradation of stably expressed ATP7B in wild type as well as Wilson disease-mutated cells [39]. The same was then shown for ATP7A [40]. Indeed, both of these ATPases bind COMMD1, as well as clusterin (a chaperone protein that attempts to restore structure), as shown by co-immunoprecipitation [41]. Interestingly, stably (but not transiently) overexpressing either of these proteins in HEK cells resulted in enhanced degradation of both ATPases, but by different apparent mechanisms. High levels of COMMD1 resulted in less ATP7A and B protein that was prevented by the proteasomal inhibitor, MG132, while the effects of high levels of clusterin were prevented by the lysosomal inhibitors, ammonium chloride and leupeptin. Degradation of oxidized and mutated ATP7B and A was also facilitated by clusterin $[40,41]$. Whether large increases in levels of COMMD1 and clusterin naturally occur, however, is unclear, and whether these two binding proteins control the normal levels of the ATPases still needs to be established, but is a possibility.

\section{Forms of $\mathrm{Cu}$ in Bile and Their Origins}

What we have described so far with regard to how $\mathrm{Cu}$ enters the bile makes the assumption that it comes from that "pumped" by ATP7B from the cytosolic Cu chaperone, ATOX1 [42]. Both ATOX1 and ATP7B bind $\mathrm{Cu}^{1+}$ via similar CXXC motifs; and so it is assumed that $\mathrm{Cu}^{1+}$ ions are released from the ATP7B either directly into the bile canaliculi, or into the TGN lumenal fluid which enters vesicles destined for biliary exocytosis. Some may also accompany ceruloplasmin into the blood in exocytic vesicles. $\mathrm{Cu}$ ions tend to bind to proteins and peptides as well as other ligands, such as glutathione. Therefore, they are likely to bind to a number of components of the developing biliary fluid. The binding may be tight or loose or in between. It may or may not be for the specific purpose of producing a component that is not digestible or reabsorbable in the gut, or has some other purpose.

Most of the available information on the forms of $\mathrm{Cu}$ present in bile comes from studies done in the 1960s to the 1980s, with very few following up in recent decades. The early studies (summarized from Linder [1]) indicated the following about the $\mathrm{Cu}$ binding components in bile: 
(a) The nature of the components varies in terms of how easily the attached $\mathrm{Cu}$ can be dialyzed away and how easily it is re-absorbed by the GI tract, as shown for example in rats injected with $100 \mu \mathrm{g}$ of ${ }^{64} \mathrm{Cu}$, measuring biliary ${ }^{64} \mathrm{Cu}$ radioactivity over time, dialyzing the bile (into $0.9 \% \mathrm{NaCl}$ ), and administering portions into new rats by intrapyloric intubation, to measure rates of intestinal uptake [1]. Table 2 shows that the bile collected early on (zero to $4 \mathrm{~h}$ after ${ }^{64} \mathrm{Cu}$ administration) had half of its $\mathrm{Cu}$ loosely bound (and released by dialysis); but dialyzability decreased substantially over time and was accompanied by greater susceptibility to TCA precipitation (a characteristic of proteins). This suggests that a portion of the $\mathrm{Cu}$ in bile becomes more tightly bound and is associated with proteins. Reabsorption of the dialyzed and undialysed biliary $\mathrm{Cu}$, however, was similar but quite low (10-15\%), reinforcing the concept that biliary $\mathrm{Cu}$ is more difficult to re-absorb than that in other GI fluids. In another study with human GI fluids (Table 2), gastric and salivary $\mathrm{Cu}$ was easily dialyzed away (85-98\%) vs. that of gall bladder bile (12\%), using $0.9 \%$ $\mathrm{NaCl} / 10 \mathrm{mM}$ Tris $\mathrm{HCl}$ buffer, $\mathrm{pH} 8$. Additionally, the absorbability of salivary and gastric fluid $\mathrm{Cu}$ (administered intraduodenally to rats) was twice that of gall bladder bile, and the same as for $\mathrm{Cu}^{2+}$-acetate or histidine.

(b) The nature and size of the biliary $\mathrm{Cu}$ components was determined largely by size exclusion chromatography of human and rat bile that had been labeled in vitro or in vivo with ${ }^{64} \mathrm{Cu}^{2+}$. It showed two major peaks in Sephadex G50 and G75, one in the void volume and the other at about $5 \mathrm{kDa}$. Bile acids (detergents like glycocholate, taurodeoxycholate and lecithin) disaggregated the larger component into the smaller one. Traces of an $8 \mathrm{kDa}$ component [43] and another below $5 \mathrm{kDa}$ [44] were also reported. Where tested, elution of these $\mathrm{Cu}$ complexes was not abolished or changed by treating with trypsin or other digestive proteases. This suggests they are not polypeptides, and would explain how they survive the gut for excretion in the feces. Alternatively, the proteins/peptides might for some other reason be resistant to degradation by digestive enzymes. The $\mathrm{Cu}$ attached to these components was bound very tightly, as it was not removed by strong chelating agents [1]. Other work suggested that one or more of these components may be fragments of ceruloplasmin that are hard to digest by proteases. In one case [45], but not another [46], some of the $\mathrm{Cu}$ of bile eluting in the void volume reacted with the antibody against ceruloplasmin. The former is consistent with physiological studies in rats by another group [47], where ceruloplasmin that had been radiolabeled in vitro with ${ }^{67} \mathrm{Cu}$ or ${ }^{64} \mathrm{Cu}$ was given i.v., and some of the radiolabeled ceruloplasmin- $\mathrm{Cu}$ ended up not only in the liver but in the bile. One caveat related to these studies, however, is that it is very difficult to insert $\mathrm{Cu}$ into ceruloplasmin in vitro, and it was not ascertained that the radiolabeled $\mathrm{Cu}$ added and used in these experiments was in its native state.)

(c) Other kinds of studies also support the idea that ceruloplasmin or its fragments can enter bile. In other rat studies, more of the radioactive $\mathrm{Cu}$ associated with ceruloplasmin entered the bile when administered as asialo-ceruloplasmin [48]. Sialic acid is known to be removed from several plasma proteins by hepatic endothelial cells. This has also been demonstrated for ceruloplasmin [48,49]. Desialylation occurred during transcytosis of the hepatic endothelial cells that form a porous layer between the blood and the hepatocytes sheaves, and the asialo-form then entered the hepatocytes via the galactose receptor $[48,49]$. In line with this, the binding of ceruloplasmin to specific "receptors" on the surface of hepatic endothelial cells but not hepatocytes was demonstrated histologically and through binding studies by Tavassoli et al. [50]. If ceruloplasmin enters hepatocytes via the galactose receptor, it will be transferred into the lysosomal compartment, which is also a source of bile components (Figure 4). These various studies (which have not been followed up) suggested that a portion or fragment of asialo-ceruloplasmin could be the main form of biliary $\mathrm{Cu}$ not re-absorbed by the intestine that ends up in the feces.

The only recent studies on the $\mathrm{Cu}$ components of bile appear to be those from fish, carried out in connection with detecting $\mathrm{Cu}$ pollution in lakes, and measuring levels of metallothioneins (MTs) in liver and bile. MTs store $\mathrm{Cu}, \mathrm{Zn}$ and some other heavy metal ions. To determine whether MT was in 
bile, and that its levels reflected heavy metal pollution (including that of $\mathrm{Cu}$ ), bile from $\mathrm{Cu}$-loaded and normal Tilapia fish was first treated with heat to precipitate non-MT proteins, and the supernatant was applied to size exclusion HPLC-ICP-MS using Superdex 75 [51]. Whether heat treatment did indeed denature and precipitate most the proteins and/or ceruloplasmin in the bile is unknown. As in the earlier studies summarized in the paragraphs above, there was a major peak in the void volume in the case of fish living in $\mathrm{Cu}$ contaminated water (Figure 5B dark line). There also were not just one but 4-5 $\mathrm{Cu}$ peaks in the included volume, one of which also contained most of the $\mathrm{Zn}$ and so might be MT. The included-volume peaks (but not the void volume peak) were also present in bile from fish living in the reference (low metal contamination) site (Figure 5A), where the $\mathrm{Zn}$ content of a peak in the MT position was the most prominent also for $\mathrm{Cu}$. This same peak (at $\sim 19 \mathrm{~min}$ ) was the main one binding Zn in fish from water highly contaminated with Zn (Figure 5C), and the authors indicate that pure MT had eluted there in previous studies using the same column and conditions. The investigators did not confirm that this peak was indeed MT, but they detected MT in whole bile immunologically (by Western blotting). The authors also did not calculate the apparent mass of the peaks they separated from the heat-treated bile samples (the apparent molecular weight of MT is $14 \mathrm{kDa}$ ). Thus, whether any of the peaks (and if so which) might correspond to the $5 \mathrm{kDa}$ Cu component seen in mammalian bile in the past is unclear. The investigators also did not attempt to dissociate the Vo peak with detergent, which previously moved $\mathrm{Cu}$ from the large to the $5 \mathrm{kDa}$ component. In any event, it seems that at least when fish are Cu-loaded, some $\mathrm{Cu}$ enters the bile on MT, and this may also be true for humans and other mammals. In follow-up studies of fish, the authors did find that levels of MT in the liver correlated well with those of MT-Cu found in bile, as would be expected [52]. Therefore, bile appears to contain Cu-binding components that vary in their size and absorbability, and at least small amounts or parts of some $\mathrm{Cu}$ proteins (ceruloplasmin and metallothionein) can be there. Obviously, much remains to be learned about the exact nature and relative abundance of these molecules and their roles in $\mathrm{Cu}$ excretion versus reabsorption.

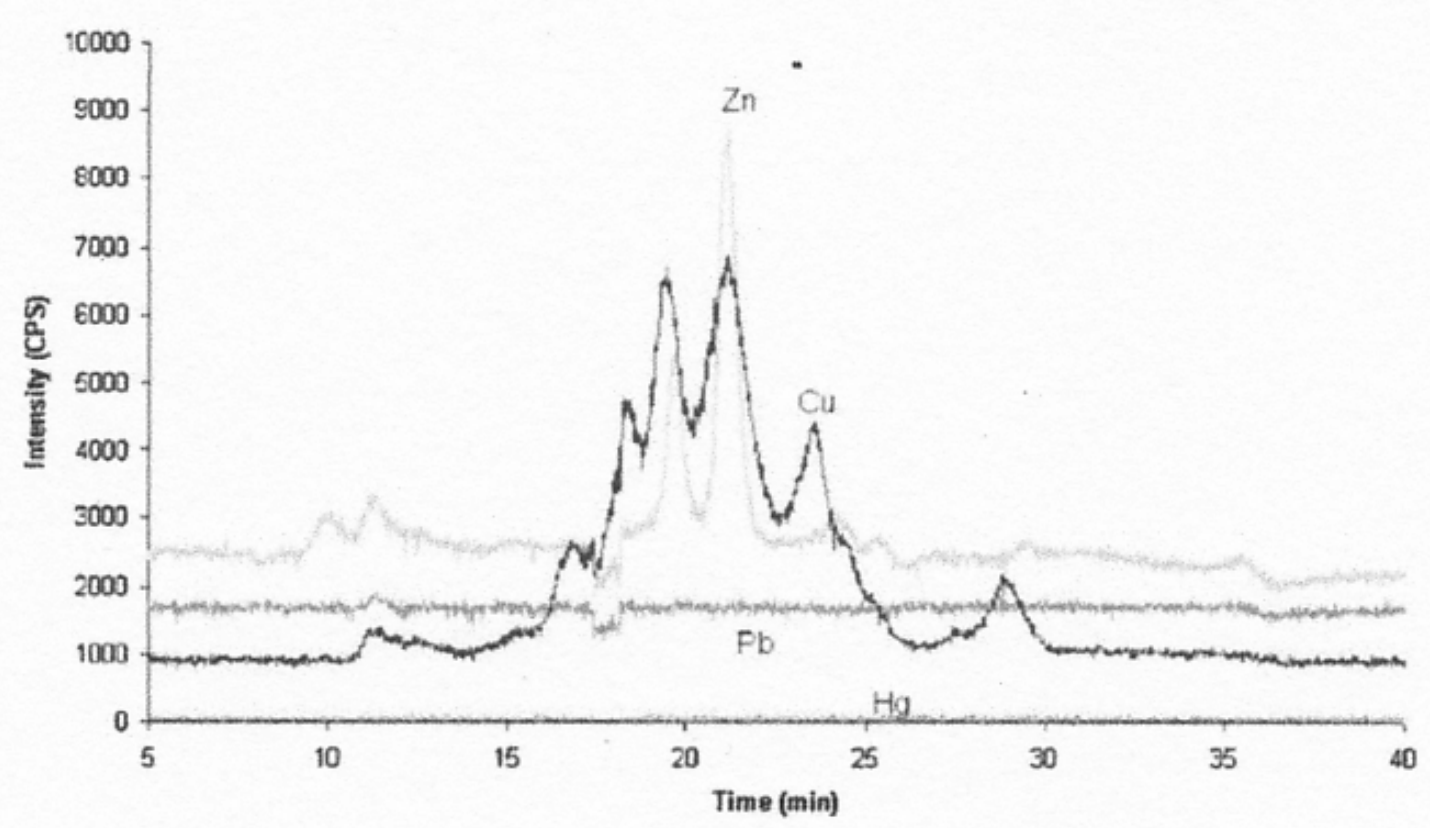

(A)

Figure 5. Cont. 


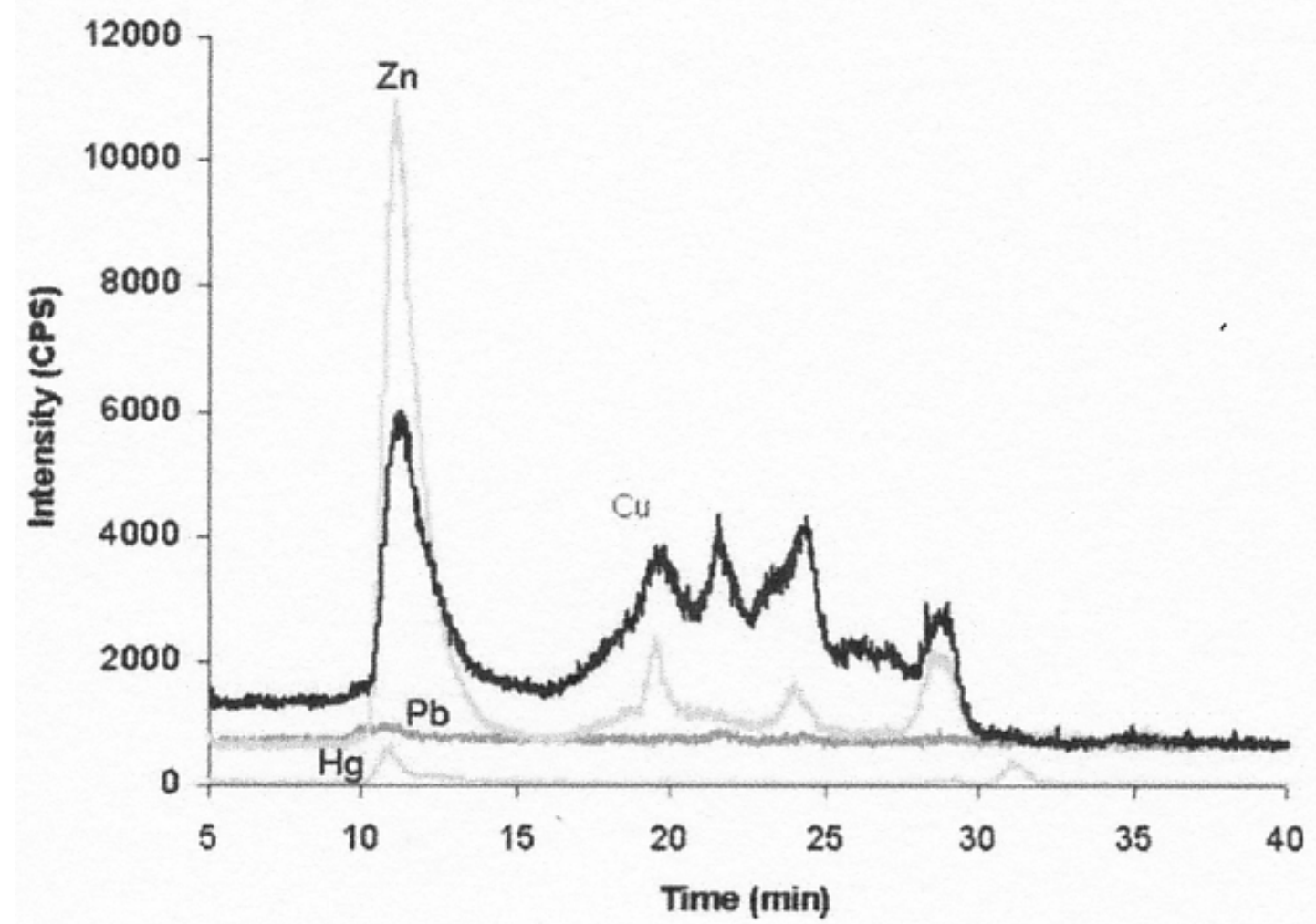

(B)

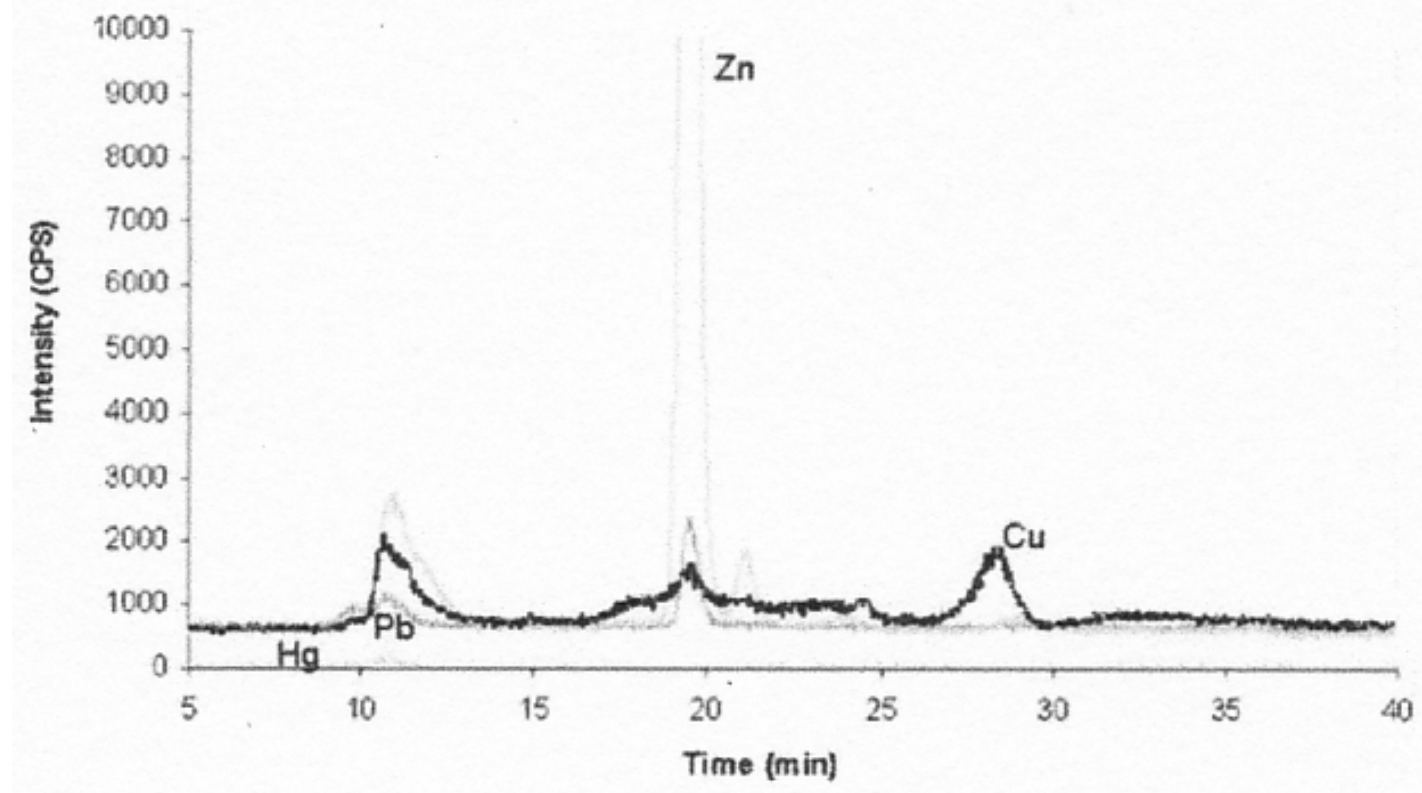

(C)

Figure 5. Metallothionein (MT) and other $\mathrm{Cu}$ components in fish bile separated in size exclusion chromatography (SEC) coupled to ICP-MS. Bile samples were first heated to remove most other proteins by precipitation, and the supernatants (containing MT) were applied to SEC. Elution of Cu and some other metal ions is shown for bile obtained from fish in uncontaminated waters (A), in Cu contaminated waters (B), and in waters containing excess $\mathrm{Zn}(\mathrm{C})$. X-axis is time (from 5 to $40 \mathrm{~min}$ ); Y-axis is metal isotope intensity for $\mathrm{Cu}$ (black), $\mathrm{Zn}$ (light grey), as well as $\mathrm{Pb}$ (dark grey) and $\mathrm{Hg}$ (very pale). Reprinted with permission from Hauser-Davis et al. [51]. 


\section{Forms of $\mathrm{Cu}$ in Other GI Fluids and Their Origins}

As already described, most of the $\mathrm{Cu}$ absorbed by the intestine that enters hepatic cells from the portal vein is from fluids that had been secreted into the GI tract. This $\mathrm{Cu}$ needs to return to the various cells that produced the secretions to complete the homeostatic loop. We have already described the route taken by $\mathrm{Cu}$ to the bile after entry into hepatocytes. Since evidence indicates that normally, most absorbed $\mathrm{Cu}$ first goes to the liver, we need to explore what is known about how $\mathrm{Cu}$ returns from the liver to those secretory cells and organs that provide saliva, as well as gastric and pancreatic juices.

So far, we have only described our current understanding of the main ways in which $\mathrm{Cu}$ leaves hepatic cells, which is by incorporation into ceruloplasmin (in the TGN) for secretion into the blood and interstitial fluid via exocytosis; and transfer across the apical portions of the plasma membrane into the developing bile in the canaliculi. Ceruloplasmin is a major distributor of $\mathrm{Cu}$ via the circulation, and delivers it directly to $\mathrm{Cu}$ uptake transporters, such as $\mathrm{Cu}$ transporter 1 (CTR1), on the surface of many cell types, producing apo-ceruloplasmin in the process [53]. Nevertheless, it seems highly unlikely that even normally (vs. in aceruloplasminemia), ceruloplasmin is the only way in which all this $\mathrm{Cu}$ leaves the liver and enters the circulation to return $\mathrm{Cu}$ to where it is needed for GI fluid production. Unfortunately, we have almost no information that allows us to estimate how much $\mathrm{Cu}$ is released from the liver via ceruloplasmin daily, and thus how much it might be contributing to $\mathrm{Cu}$ recycling for GI tract fluids. Rat studies in which the relative half-life of ceruloplasmin protein was calculated (obtained by double labeling with ${ }^{3} \mathrm{H}$ - and ${ }^{14} \mathrm{C}$-leucine) only indicated that the turnover rate of ceruloplasmin was 3-4 fold higher than that for plasma proteins as a whole [23]. Clearly, $\mathrm{Cu}$ in the bloodstream is also bound to proteins other than ceruloplasmin and potentially also to non-protein molecules. Humans and mice with no ceruloplasmin in the circulation survive fairly well overall, although not without some complications involving both $\mathrm{Cu}$ and Fe metabolism [54-57]. In Wilson disease (with no functional ATP7B to incorporate $\mathrm{Cu}$ into ceruloplasmin), there still is $\mathrm{Cu}$ in the blood, and subjects lead relatively normal lives as long as they are treated with chelators to remove the excess $\mathrm{Cu}$ [3]. So how does the $\mathrm{Cu}$ in hepatocytes get back into the circulation from the liver other than on ceruloplasmin, and in what other form(s) is it released?

One obvious possibility is that $\mathrm{Cu}$ entering the TGN through ATP7B from ATOX1 does not just go into ceruloplasmin but also binds to other as yet unknown factors that lead to its secretion, perhaps even accompanying ceruloplasmin in exocytic vesicles that fuse with the (basolateral) plasma membrane (Figure 4). Another obvious possibility is secretion via ATP7A (Figure 4). The homologous $\mathrm{Cu}$ "pumps", ATP7A and ATPB, carry out $\mathrm{Cu}$ transport in different ways. While ATP7B is expressed in a limited number of cell types (notably the hepatocyte and mammary epithelial cells) and provides $\mathrm{Cu}$ to secreted proteins (such as ceruloplasmin in hepatocytes, and lysyl oxidase in fibroblasts, ATP7A is expressed in most cells and mainly releases $\mathrm{Cu}$ into the blood not bound to proteins [58,59]. Thus, knocking out ATP7B prevents or markedly reduces $\mathrm{Cu}$ entering ceruloplasmin or the bile, causing hepatic $\mathrm{Cu}$ accumulation, while knocking out ATP7A greatly diminishes the transfer of cellular $\mathrm{Cu}$ into the blood, the most notable example being the release from enterocytes during intestinal absorption. However, it has become clear that hepatic cells express not only ATP7B but also some ATP7A [38], and this would ostensibly contribute to the transfer of $\mathrm{Cu}$ from the liver to the rest of the organism.

The form in which this $\mathrm{Cu}$ emerges after being pumped across membranes by ATP7A and ATP7B is not entirely clear. Delivery of the $\mathrm{Cu}$ to these membrane transporters occurs via binding to CXXC motifs as $\mathrm{Cu}^{1+}$ on ATOX1 [60], followed by transfer to the same kinds of motifs on ATP7A or B. Thus, $\mathrm{Cu}$ appears to enter into the membrane transporters as $\mathrm{Cu}^{1+}$ in line with the reducing environment of the cytosol. If, on the other side of the membrane, the $\mathrm{Cu}$ released is also $\mathrm{Cu}^{1+}$, with ATP7A it would enter the non-reducing (oxidizing) environment of the blood fluid. Based on radiotracer studies, $\mathrm{Cu}$ released by ATP7A after intestinal absorption immediately appears on albumin and transcuprein (macroglobulin) in the blood plasma [14], and these proteins bind $\mathrm{Cu}^{2+}[61,62]$. Therefore, the $\mathrm{Cu}^{1+}$ would have to be oxidized after release. This could just be induced by oxygen itself coursing through the blood. Alternatively, $\mathrm{Cu}^{1+}$ might be oxidized during transit through the transporter. Whether the 
$\mathrm{Cu}^{1+}$ delivered by ATP7B to the TGN lumen also encounters an oxidizing environment is unclear, but is also less likely. Still another possibility has been proposed, namely that both ATP7A and B might be able to transport not only ionic $\mathrm{Cu}$ but also metal complexes, such as the anticancer drug cisplatin and its analogs $[63,64]$. Mediation of uptake of these drugs by cells and their transfer across internal membranes has been demonstrated to involve other $\mathrm{Cu}$ transporters, namely CTR1 and CTR2, respectively $[65,66]$. Uptake of these complexes may, however, not take the same route as that for the $\mathrm{Cu}$ ion, and more studies are needed to clarify whether and how metal complexes (as opposed to $\mathrm{Cu}$ ions) interact with these various transporters.

Other as yet unknown ways by which hepatocytes release $\mathrm{Cu}$ in some form may also exist. As already indicated, ionic $\mathrm{Cu}$ released from hepatocytes will bind to albumin and transcuprein [67] and perhaps also to other proteins and/or peptides that make up the exchangeable $\mathrm{Cu}$ pool in the blood plasma. It will travel on these proteins (as well as ceruloplasmin) in the circulation, and, despite binding tightly, be delivered directly to transporters (or transporters complexed with reductases to reduce $\mathrm{Cu}^{2+}$ ) on the surface of cells, as shown in tissue culture with several types of cells $[53,68,69]$. Except for CTR1, the $\mathrm{Cu}$ uptake transporters involved have not as yet been identified $[53,68,69]$. Cells of the salivary gland, as well as those of the gastric mucosa and pancreas that produce GI secretions, would thus receive the $\mathrm{Cu}$ they need from one or more of these carrier proteins, via CTR1 and $\mathrm{Cu}$ uptake transporters.

Once inside the cell, the $\mathrm{Cu}$ would find its way to the secretory pathway, and specifically to the TGN, carried on the $\mathrm{Cu}$ chaperone ATOX1. In the TGN, the $\mathrm{Cu}$ would encounter and be incorporated into the specific $\mathrm{Cu}$ components that are secreted in saliva, gastric, pancreatic and other fluids into the GI tract by exocytosis. What is known about the forms of these components, and the most recent information on the amounts of $\mathrm{Cu}$ associated with these fluids, is described below.

Salivary Copper: There are a few articles in the more recent literature reporting concentrations of this metal in whole/crude saliva and sub-fractions, from normal individuals and those with diseases like cancer of the head and neck [70] and oral submucous fibrosis [71], involving groups of 20-60 subjects. The reported total $\mathrm{Cu}$ concentrations in normal saliva are in the ballpark but lower than those reported in earlier decades (more like $0.1 \mathrm{vs} 0.2 \mathrm{mg} / \mathrm{L}$, or $\sim 1.5 \mu \mathrm{M}$ ). Few attempts have been made to identify to what salivary $\mathrm{Cu}$ is bound. One group approached this question by adding $\mathrm{Cu}$ to saliva samples, and then separating components by size, shape or other means [72]. To pooled saliva from 5 individuals, $\mathrm{Cu}\left(\mathrm{as} \mathrm{CuSO}_{4}\right)$ was or was not added to final concentrations of $10-40 \mu \mathrm{g} \mathrm{Cu} / \mathrm{L}$, following which samples were examined for changes in what proteins were present in supernatants, after sedimentation $(16,000 \times g, 5 \mathrm{~min})$, or in response to $5 \mathrm{kDa}$ ultrafiltration, and/or upon separation in reverse phase HPLC followed by SDS-PAGE. The findings appear to be contradictory. On the one hand, $85 \%$ of the inherent $\mathrm{Cu}$ was ultrafiltrable from crude saliva not treated with $\mathrm{Cu}$, thus being in small molecules $<5 \mathrm{kDa}$. Addition of $10 \mu \mathrm{M}$ ionic $\mathrm{Cu}$ further increased that proportion to $95 \%$, perhaps indicating that the excess $\mathrm{Cu}$ was still in ionic form, and thus exceeded the $\mathrm{Cu}$ binding capacity of the saliva sample. On the other hand, addition of much higher levels ( $40 \mu \mathrm{g} \mathrm{Cu} / \mathrm{L}$ as $\mathrm{Cu}$ sulfate) precipitated portions of the main known salivary proteins, implying that the $\mathrm{Cu}$ was binding to them. This reduced the specific proteins remaining in the supernatant that were applied to reverse phase HPLC. The most dominant proteins in the saliva that precipitated with the $\mathrm{Cu}$ were alpha-amylase (51-54 kDa) and basic proline-rich proteins (PRPs; $11 \mathrm{kDa}$ [73]). With lower $\mathrm{Cu}$ concentrations ( 5 and $10 \mu \mathrm{g} / \mathrm{L}$ ), there was less precipitation, but also an increase in $\mathrm{Cu}$ associated with HPLC peaks that contained proteins of 29 and $33 \mathrm{kDa}$. These proteins were not identified, but the authors concluded they are unlikely to be PRPs. Thus, we really do not know to what $\mathrm{Cu}$ is bound in saliva, particularly under normal conditions, but it seems that at lower (more physiological) concentrations, namely $1-2 \mu \mathrm{M}$, most of the $\mathrm{Cu}$ is associated with a component (or components) of low molecular weight $(<5 \mathrm{kDa})$.

In line with this, it has been known for some time that saliva contains a group of basic, histidine-rich peptides, histatins, that can bind with copper and are 3-4 kDa in mass [74-76]. They contain N-terminal amino acid residues that form the "amino terminal $\mathrm{Cu}(\mathrm{II}), \mathrm{Ni}(\mathrm{II})$ " (ATCUN) binding motif, first found in albumin, but bind $\mathrm{Cu}(\mathrm{II})$ with lower affinity ( $\mathrm{Kd}$ in the range of $10^{-7}-10^{-8}$, vs. $10^{-11}$ or lower) [74]. 
Histatins are known for their antifungal (as well as healing) properties, and antifungal activity is associated with the $\mathrm{N}$-terminal region of the peptide. Recent studies have shown that activity against yeast (candida albicans) increased 5-fold upon the addition of $\mathrm{Cu}$ (II) in the case of histatin-5, $\mathrm{EC}_{50}$ concentrations falling from $\sim 5$ to $\sim 1 \mu \mathrm{M}$ [74]. Two His residues near the ATCUN motif were also important for the enhancement of antifungal activity, and other adjacent residues forming a $\mathrm{Cu}(\mathrm{I})$ complex may be important. It is noteworthy that the exposure of histatins to saliva, which contains some proteases, did not destroy the antifungal portions, at least initially [76]. However, in saliva, histatin- 5 can bind salivary proteins, including amylase, and amylase binding inhibits its antifungal activity [77]. Whether histatins are secreted with $\mathrm{Cu}$ attached, however, is unknown. Most salivary $\mathrm{Cu}$ is with material less than $5 \mathrm{kDa}$ and thus might be with histatins. Alternatively, traces of $\mathrm{Cu}$ ions in water or freed from food during initial digestion in the mouth might bind to the histatins.

Copper in Gastric, Pancreatic and Duodenal Fluids: Reports on the $\mathrm{Cu}$ contents of gastric and duodenal juices per se are hard to find, in part perhaps because it is difficult to obtain "pure" samples not contaminated with secretions from other sources, like saliva in the stomach, and pancreatic and biliary fluids in the upper small intestine. Data compiled by Owen in 1982 (covering reports from the 1950s to the 1980s) [78] gave a value of $0.4 \mathrm{mg} / \mathrm{L}(\sim 6 \mu \mathrm{M})$ for gastric juice [1], and the only more recent one discovered [79] gave a 5 -fold lower value $(1.2 \mu \mathrm{M})$. In the latter case, pains were taken to preclean the gastroscope used for sampling (which was demonstrated to be a source of contamination). Therefore, the lower value may be more reliable. Assuming that an average of $2.5 \mathrm{~L}$ of gastric juice are secreted per day [1] at a concentration of $1.2 \mu \mathrm{M}$, the daily excretion of $\mathrm{Cu}$ through gastric fluid would amount to $0.18 \mathrm{mg}$ of $\mathrm{Cu}$. No reports on the $\mathrm{Cu}$ contents of actual duodenal secretions were found, except as a way to determine the contribution of pancreatic fluid, by measuring the increase in $\mathrm{Cu}$ in the duodenum in response to secretin [80]. However, anecdotally, in our laboratory we have used enterocytic monolayers of $\mathrm{Caco} 2$ cells with tight junctions grown on filters in bicameral chambers and found that radioactively labeled $\mathrm{Cu}$ ions administered to the basolateral ("blood" side) rapidly move through the cells and are released at the apical surface, i.e., into the "intestinal lumen" (Luis Corona, Theodros Z. Kidane, Maria C. Linder, unpublished). The nature of this $\mathrm{Cu}$ has not been investigated. For pancreatic fluid, there are more determinations, and recent values corroborate those of the past ( 0.32 versus $0.25-0.35 \mathrm{mg} \mathrm{Cu} / \mathrm{L}$ ) [81,82], which roughly corresponds to $0.4-0.5 \mathrm{mg}$ secreted per day. In all cases, subjects had fasted and were given secretin to stimulate release. Again, very little is known about the nature of the $\mathrm{Cu}$ found in these fluids. $\mathrm{Cu} / \mathrm{Zn} \mathrm{SOD}$ (SOD1) was detected in the first portion of pancreatic juice released in response to secretin, but its concentrations fell to very low levels after stimulation with cholecystokinin [11]. All this shows that we still have much to learn about the forms in which $\mathrm{Cu}$ is secreted from these various cell types as part of $\mathrm{Cu}$ homeostasis.

\section{Forms of $\mathrm{Cu}$ in Other Fluids and Their Origins}

$\mathrm{Cu}$ in Urine: In comparison with the amounts of $\mathrm{Cu}$ lost from the GI tract on a daily basis ( $\sim 1 \mathrm{mg}$ for the average adult human), those normally lost via the urine are much lower, typically $40-50 \mu \mathrm{g} /$ day [1,83], but are quite variable: $0.05-0.4 \mu \mathrm{g} / \mathrm{mg}$ creatinine [1,84], and about $12+7 \mu \mathrm{g}$ $\mathrm{Cu} / \mathrm{L}(\mathrm{Mean}+\mathrm{SD})$ in pregnant women near term [85]. Urinary $\mathrm{Cu}$ could come from two sources, namely the blood plasma (filtered through the glomerulus) and/or as secretions from certain kidney cells in the tubules. Concerning the latter possibility and as already described, the $\mathrm{Cu}$ transporters ATP7A and ATP7B are important mediators of Cu release from cells, whether located in the TGN membrane or trafficking, moving via vesicles to portions of the cell plasma membrane. The protein and mRNA expression of these transporters was examined histologically in different portions of the kidney of normal mice by two different groups $[86,87]$ and yielded partly contradictory results for ATP7A. Grimes et al. [86] found that it was mainly in cells of the proximal and distal tubules, with slight expression in glomerular cells. Moore and Cox [87] found predominant expression in the glomeruli. Either way, expression associated with cells of the nephron raises the possibility that ATP7A might be pumping $\mathrm{Cu}$ into kidney tubules for excretion (although it normally pumps $\mathrm{Cu}$ into the blood). 
For ATP7B, Moore and Cox [87] found it was expressed in the glomeruli as well as in the inner and outer zones of the medulla, presumably associated with the loops of Henle. This localization might support a role for ATP7B in secreting $\mathrm{Cu}$ into the tubules and thus might also be entering the urine. However, Moore and Cox suggested instead that ATP7B is retrieving $\mathrm{Cu}$ from the tubular lumen i.e., is helping to re-absorb it, but this has not been followed up. Further studies by the groups of Lutsenko, Kaplan and Hubbard confirmed the presence of both ATP7A and B in cells of the proximal and distal tubular epithelia $[23,88]$, and discovered that ATP7A but not ATP7B trafficked from the TGN to the cellular periphery near the blood in response to excess $\mathrm{Cu}$ [88]. This is consistent with the general concept that ATP7A exports $\mathrm{Cu}$ from epithelial cells into the blood and would explain why excess $\mathrm{Cu}$ does not accumulate in renal epithelia in $\mathrm{Cu}$ overload. (The latter was observed in Atp7b-/- mice.) The reason ATP7B failed to traffic from the TGN to the cell periphery in response to $\mathrm{Cu}$ treatment [88] was ascribed to the fact that a modified (2-3 kDa shorter) form was expressed. Indeed, these investigators proposed that in this form, ATP7B might have the role of pumping excess $\mathrm{Cu}$ into vesicles for storage. The latter findings suggest that it is unlikely that either of these transporters directly mediate secretion of $\mathrm{Cu}$ into the renal tubules for excretion in the urine, although it is clear that follow-up is needed.

With regard to blood plasma as a $\mathrm{Cu}$ source for the urine, very little $\mathrm{Cu}$ is normally associated with components sufficiently small to pass through the glomerular fenestrations, which permit materials up to about $30 \mathrm{kDa}$ to pass, most of which are re-absorbed. Only very small amounts of low molecular weight material binding $\mathrm{Cu}$ have been detected in normal plasma [65], and small amounts of $\mathrm{Cu}$ are also associated with other components (most likely proteins) smaller than albumin and possibly of a size that might penetrate the glomeruli. However, there normally is very little $\mathrm{Cu}$ in the urine, and what little evidence we have suggests it is mainly quite small in size. For example, already in 1981 Suzuki and colleagues $[89,90]$ reported that a major portion of urinary Cu eluted at the end of the column volume in size exclusion chromatography on Sephadex G75. Size exclusion separation and $\mathrm{Cu}$ analyses of blood plasma from many species has established that traces of $\mathrm{Cu}$ are associated with very small components $[67,91]$. Figure 6 shows that most of the $\mathrm{Cu}$ eluted from whole blood plasma of different species in size exclusion FPLC on Superdex 200 eluted with large proteins, but small and variable amounts eluted with low molecular weight components, centering on fraction $43(\sim 86 \%$ of the column volume). In preliminary recent studies of normal human plasma in our own laboratory, individuals had detectable $\mathrm{Cu}$ in $3 \mathrm{kDa}$ ultrafiltrates averaging $4.4+1.2 \mathrm{ng} / \mathrm{mL}$ (mean $+\mathrm{SD} ; \mathrm{N}=4$ ) (Alex Nguyen, Maria C Linder, unpublished data), which one would expect would be filtered by the kidney. Thus, blood fluid of normal mammals can contain very small amounts of one or more low molecular weight $\mathrm{Cu}$-containing components that could be entering the urine. One of the other smaller components in urine may be metallothioneins (SEC Mr $\sim 14 \mathrm{kDa}$; actual mass $\sim 8 \mathrm{kDa}$ ), which have been detected there, particularly in the case of copper-loaded rats [12], and can also be present in the bile (see earlier).

Studies of $\mathrm{Cu}$ overload are adding to our understanding of urinary $\mathrm{Cu}$. When there is overload, as in Wilson disease (WD), as well as in animals fed high $\mathrm{Cu}$ diets or injected with large amounts of $\mathrm{Cu}$, urinary $\mathrm{Cu}$ levels rise dramatically. For example, in rats on a high $\mathrm{Cu}$ diet, urinary $\mathrm{Cu}$ increased 2.5-fold in 5 weeks, and 4-fold by 16 weeks (liver MT increased 3.5-5-fold) [12]. In human WD subjects, Walshe reported that pre-symptomatic patients excreted an average of $208 \mu \mathrm{g} \mathrm{Cu} / 24 \mathrm{~h}$ [92], compared with about $40 \mu \mathrm{g}$ in normal subjects [83]. WD patients with full blown hepatic and neurological WD had even higher average levels, excreting an average of 466 and $306 \mu \mathrm{g} /$ day in the urine, respectively [92]. Figure 7A shows data from Gray et al. [92] on the elution of large amounts of urinary Cu by WD model mice, compared to controls, in conjunction with accumulation of large amounts of $\mathrm{Cu}$ in the liver (Figure 7B). In this case, a large increase in the levels of low-molecular weight $\mathrm{Cu}$ in the blood plasma was also observed [67] (Figure 7C). This would be consistent with the latter being responsible for the former, i.e., low-molecular weight $\mathrm{Cu}$ in the plasma was filtering into the urine. We obtained further preliminary results on $3 \mathrm{kDa}$ ultrafiltrates of plasma and urine from Labrador retrievers without and with ATP7B mutations and $\mathrm{Cu}$ overload, showing that a lack of ATP7B function markedly increased 
levels of low-molecular weight $\mathrm{Cu}$ in both fluids, relative to the norm (wild type) (Figure 8). Thus, blood fluid rather than kidney cells is most probably the main source of the increased low-molecular weight $\mathrm{Cu}$ excreted in the urine of $\mathrm{Cu}$ overloaded animals, and the same is likely to be true in humans.

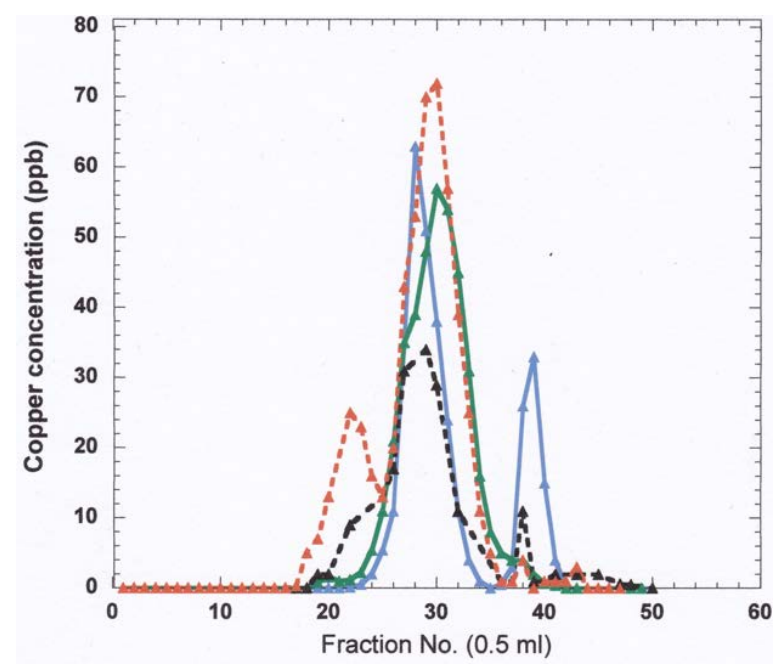

Figure 6. Separation of $\mathrm{Cu}$ components of blood plasma from various species showing some $\mathrm{Cu}$ eluting at the end of the column volume, where the small Cu carrier (SCC) elutes. Whole plasma samples $(100 \mathrm{uL})$ from humans (red), pigs (blue), sheep (green), and cows (black) were applied to a $25 \mathrm{~mL}$ column of Superdex 200, and the Cu content of $0.5 \mathrm{~mL}$ fractions collected was measured by furnace atomic absorption spectrometry (Linder et al., unpublished.) The peak of ceruloplasmin elution is in the region of fraction 29-30, and albumin is right after. Alpha-2-macro-globulin elution peaks at about fraction 22.

A

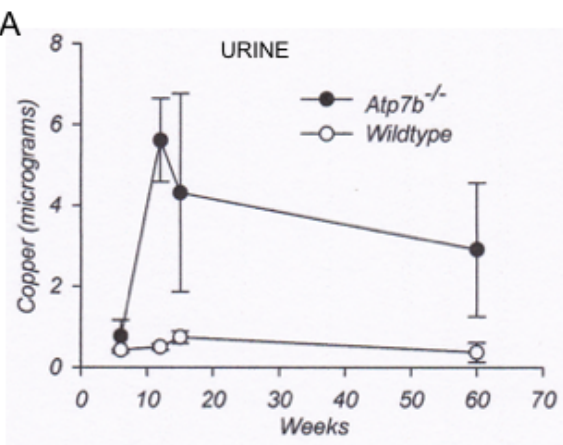

B

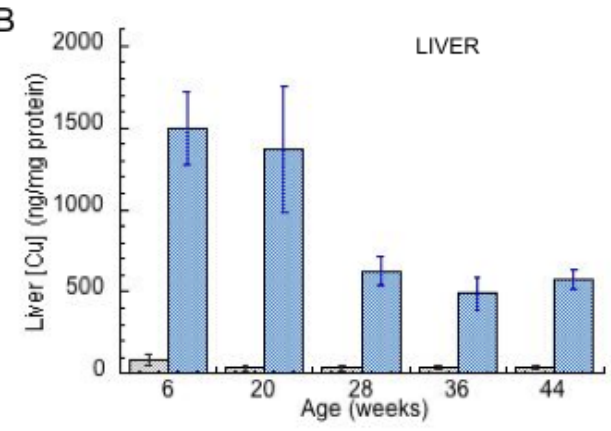

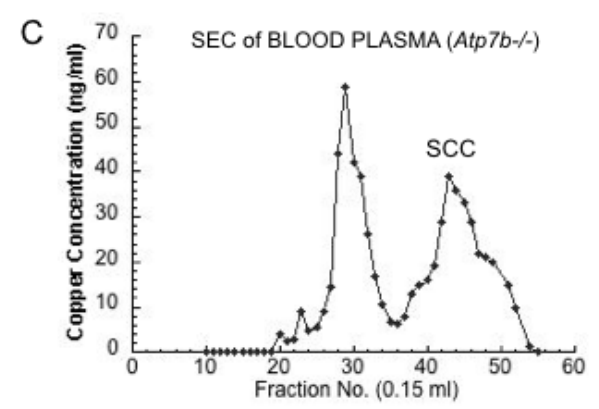

Figure 7. $\mathrm{Cu}$ in livers, urine and blood plasma of wild type (Control) and Wilson disease (Atp7b-/-) model mice. Elevations of urinary $\mathrm{Cu}(\mathrm{A})$ and liver $\mathrm{Cu}(\mathbf{B})$ (blue vs. grey bars) in the Atp7b-/mice vs. wild type, and evidence for the presence of large amounts of low molecular weight $\mathrm{Cu}$ in the blood plasma (C) seen in Superdex 200 size exclusion chromatography (SCC, fractions 40-50). Figure A reprinted with permission, from Gray et al. [93]; data in B replotted from those in Table 1 of Huster et al. [94]; data in C are from Miguel Tellez, Abigael Muchenditsi, Svetlana Lutsenko, and Maria C. Linder, unpublished. 

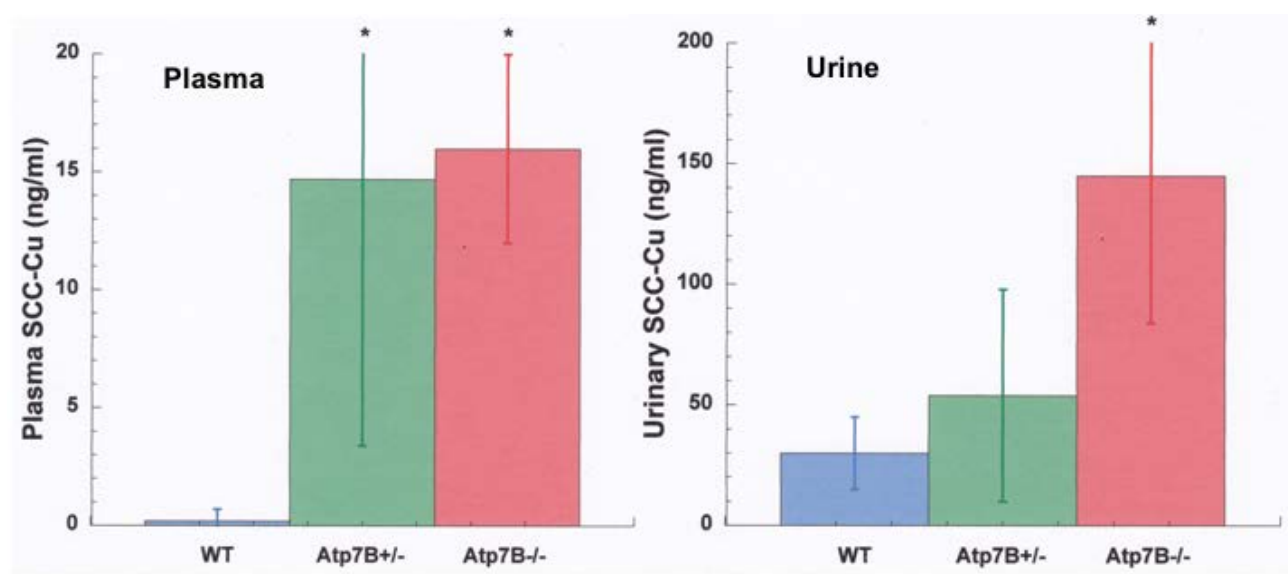

Figure 8. Levels of $\mathrm{Cu}$ associated with the small copper carrier (SCC) in the plasma (left) and urine (right) of Labrador retrievers that do and do not have defects in Atp7B, relative to the wild type. Values are for $\mathrm{ng} / \mathrm{mL} \mathrm{Cu}$ in $3 \mathrm{kDa}$ ultrafiltrates (Means + SD) for blood plasma (left) and urine (right) of wild type controls (blue), and for retrievers with hetero (green) and homozygous (red) defects in Atp7b (5-6 animals/group). Pooled ultrafiltrate samples eluted as a single peak of $\sim 1.7 \mathrm{kDa}$ by size exclusion chromatography from a small pore gel column (Superdex 30 Increase) (not shown). From Sai Vallabhaneni, Kaitlynne Kim, Maria C. Linder and Hille Fieten, unpublished. ${ }^{*} p<0.01$ vs. WT.

These various findings imply that under normal conditions, the very low levels of $\mathrm{Cu}$ in urine are associated with mostly unknown components, but might include MT and possibly other minor substances secreted into urinary tubules by kidney epithelial cells, as well as traces of a low molecular weight component also found in the blood fluid. However, when there are large increases either in the intake/absorption of $\mathrm{Cu}$ from the diet and/or genetic changes that cause liver $\mathrm{Cu}$ accumulation, urinary $\mathrm{Cu}$ excretion can markedly expand, and most of the additional $\mathrm{Cu}$ entering the urine probably comes from low molecular weight $\mathrm{Cu}$ in the blood plasma. The nature of the main components, termed the small copper carrier (SCC), appearing in the urine in $\mathrm{Cu}$ overload, was initially investigated by Gray et al. [93] using size exclusion and anion exchange chromatography, with the outcome that it was $1-2 \mathrm{kDa}$, and had a negative charge at neutral $\mathrm{pH}$. Further characterization of this SCC is in progress, mainly in our laboratory, and confirms it is an anion (by native PAGE and isoelectric focusing), may have a mass to charge ratio of 845 (determined by electrospray MS), and contains $\mathrm{Cu}^{2+}$ most likely bound to $\mathrm{N}$ and $\mathrm{O}$ ligands (determined by EPR) [Bertrand Vileno and Maria Linder et al., unpublished]. Purification of sufficient amounts of this component for structure determination is proceeding. The small $\mathrm{Cu}$ carrier is secreted by several cultured cell types, and thus may have an important role not only to reduce excessive copper loads in the liver and other organs by enhancing its urinary excretion [92] but also in the distribution of $\mathrm{Cu}$ to other tissues via the circulation, all of which are related to mammalian $\mathrm{Cu}$ homeostasis. Whether (and, if so, how) this SCC may relate to the

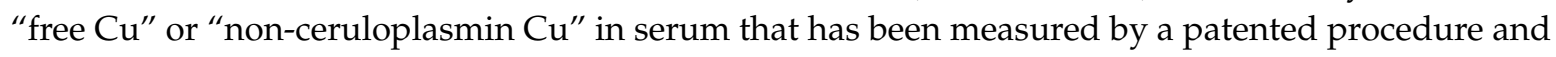
may relate to Alzheimer's disease [95] remains to be determined.

\section{Conclusions}

The main and best established points about how mammalian $\mathrm{Cu}$ homeostasis occurs through a balance between absorption, transport and excretion, and the important roles of secretions discussed in this review are summarized in Figure 9. The figure depicts the amounts of $\mathrm{Cu}$ entering the digestive tract from various sources and how they travel from the intestine to key organs (like liver and kidney) and the rest of the organism, as well as how $\mathrm{Cu}$ is excreted. Values indicated are average mg $\mathrm{Cu}$ per day, based on the current and earlier literature, as previously discussed. Starting with $\mathrm{Cu}$ in food and drink entering the mouth (top left; "Diet"), as well as that in salivary, gastric, biliary and pancreatic 
secretions, plus some $\mathrm{Cu}$ from the intestinal mucosal cells of the small intestine, provide $\mathrm{Cu}$ to the GI tract. Most of that is absorbed in the duodenum of the small intestine.

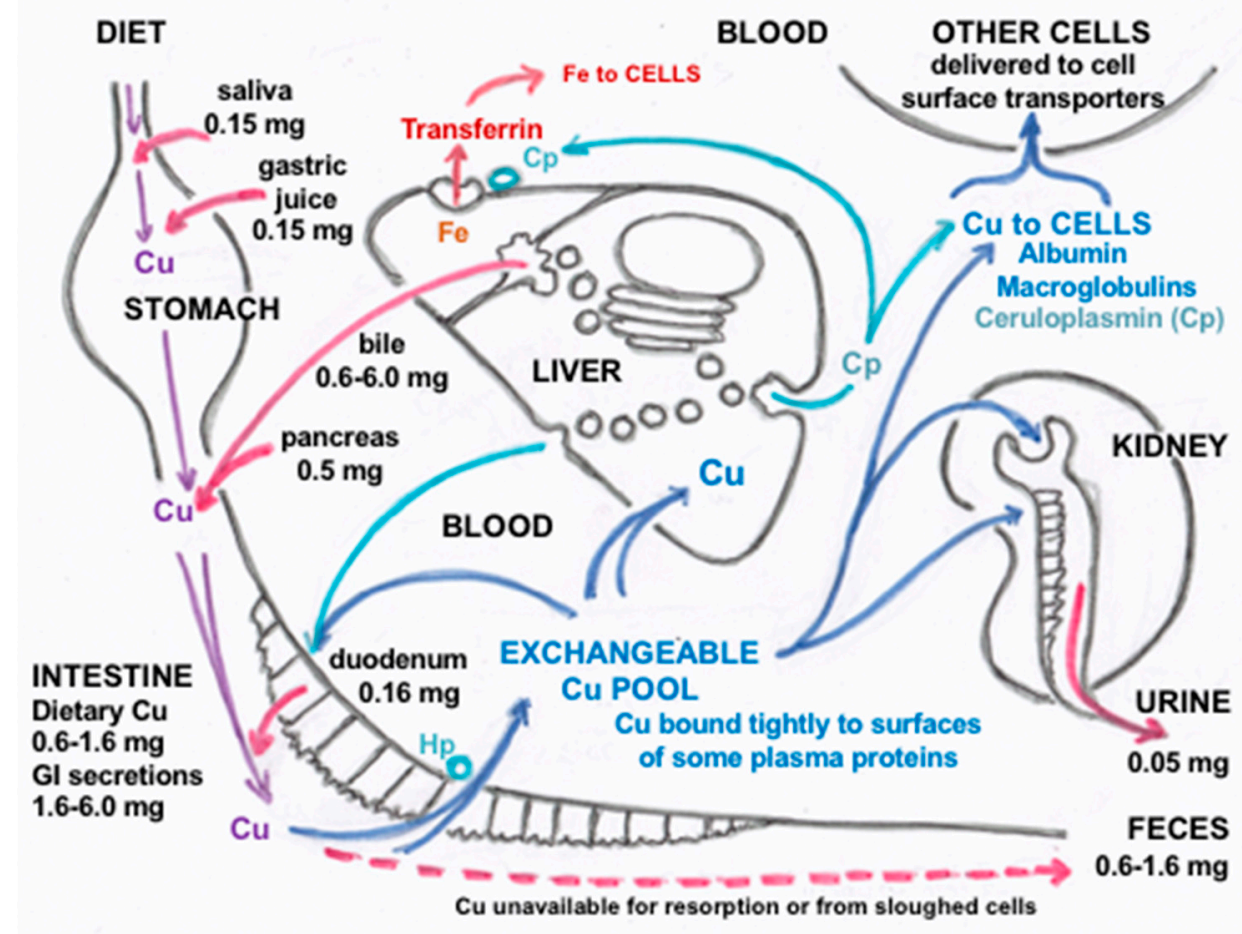

Figure 9. Overview and Summary of the homeostatic processes described in this review for the normal human adult. This figure diagrams amounts of copper entering the digestive tract from various sources and how they travel from the intestine to key organs (like liver and kidney) and the rest of the organism, as well as how copper is excreted. Values indicated are average mg $\mathrm{Cu}$ per day. Dietary $\mathrm{Cu}$ is indicated by purple lines; absorption and distribution to liver, kidney and other cells is in darker blue; involvement of ceruloplasmin (Cp) is in lighter blue; involvement of $\mathrm{Cp}$ and hephaestin (Hp) in Fe efflux from liver and intestine, respectively, is in the light blue and orange; secretions that lead to $\mathrm{Cu}$ efflux into the GI tract, feces and urine are in red. Modified and updated from Linder [9].

Transfer of absorbed $\mathrm{Cu}$ from the intestinal cells to the blood is accomplished mainly by the $\mathrm{Cu}$ ATPase (ATP7A). Based upon tracer studies with radioactive $\mathrm{Cu}, \mathrm{Cu}$ that enters the hepatic portal circulation binds tightly to proteins that compose the exchangeable $\mathrm{Cu}$ pool of the blood plasma, which consists mainly of albumin and alpha-2-macroglobulin (transcuprein), but may include other protein or non-protein components. The bulk of this $\mathrm{Cu}$ then first enters cells of the liver and partly also those of the kidney (Figure 2), where $\mathrm{Cu}$ is supplied to endogenous $\mathrm{Cu}$-dependent proteins via various chaperones (ATOX1, CCS, Cox17). Most travels to the transmembrane Cu "pump", ATP7B, in the trans Golgi network, from where a significant portion is incorporated into ceruloplasmin (Cp) for secretion into the blood via exocytosis, where it joins $\mathrm{Cu}$ on albumin and transcuprein/macroglobulin for delivery to cells in other organs all over the body (including the intestine). Another portion of $\mathrm{Cp}$ interacts with Fe (orange section of the diagram) to facilitate Fe release and transport on its blood carrier, transferrin. Hephaestin (Hp), a membrane-bound homolog of $\mathrm{Cp}$, plays a similar role in $\mathrm{Fe}$ release from enterocytes to the blood. Excess $\mathrm{Cu}$ in the liver cells finds its way into the bile after entering the bile canaliculi, with the help of ATP7B and the endo-lysosomal compartment (see Figure 4). Most excretion of $\mathrm{Cu}$ is via the bile, as biliary $\mathrm{Cu}$ is not as readily re-absorbed, and so ends up in the feces. Cells regularly sloughed off the intestinal mucosa and degraded in the large intestine may also contribute to fecal excretion. Normally, only a small amount of $\mathrm{Cu}$ is excreted in the urine, which probably derives not only from tubular secretions but also the filtration of blood plasma. However, 
urinary secretion markedly increases when biliary secretion is compromised, leading to increases in small Cu carriers (SCC) in blood plasma that greatly increase levels of SCC in the urine. A great deal is still unknown about the additional forms of $\mathrm{Cu}$ that may be involved in its flow, especially through various secretory pathways leading to the blood, bile and urine, and the contributions of these processes and components to mammalian $\mathrm{Cu}$ homeostasis, as described in this review.

Funding: This research received no external funding.

Acknowledgments: The author is grateful to her students and specific collaborators involved in ongoing and unpublished research mentioned in these pages, notably Svetlana Lutsenko (John Hopkins Medical Institute); Hille Fieten, Faculty of Veterinary Medicine, University of Utrecht; Peter Faller and Bertrand Vileno, Institute of Chemistry, University of Strasbourg.

Conflicts of Interest: The author declares no conflict of interest.

\section{References}

1. Linder, M.C. Biochemistry of Copper; Plenum: New York, NY, USA, 1991.

2. Linder, M.C.; Roboz, M. Turnover and excretion of copper in rats as measured with ${ }^{67} \mathrm{Cu}$. Am. J. Physiol. Endocrinol. Metab. 1986, 251, E551-E555. [CrossRef] [PubMed]

3. Czlonkowska, A.; Litwin, T.; Dusek, P.; Ferenci, P.; Lutsenko, S.L.; Medici, V.; Rybakowski, J.K.; Weiss, K.H.; Schilsky, M.L. Wilson disease. Nat. Rev. Dis. Primers 2018, 4, 21. [CrossRef]

4. Guindi, M. Wilson disease. Semin. Diagn. Pathol. 2019, 36, 415-422. [CrossRef] [PubMed]

5. Van de Sluis, B.; Rothuizen, J.; Pearson, P.L.; Wijmenga, C. Identification of a new copper metabolism gene by positional cloning in a purebred dog population. Hum. Mol. Genet. 2002, 11, 165-173. [CrossRef] [PubMed]

6. Fedoseienko, A.; Bartuzi, P.; van der Sluis, B. Functional understanding of the versatile protein copper metabolism MURR1 domain (COMMD1) in copper homeostasis. Ann. N.Y. Acad. Sci. 2014, 1314, 6-14. [CrossRef] [PubMed]

7. Haywood, S.; Boursnell, M.; Loughran, M.J.; Trafford, J.; Isherwood, D.; Liu, X.; Olohan, L.; Carter, S.D. Copper toxicosis in non-COMMD1 Bedlington terriers is associated with metal transport gene ABCA12. J. Trace Elem. Biol. Med. 2016, 35, 83-89. [CrossRef] [PubMed]

8. Linder, M.C.; Hazegh-Azam, M. Copper biochemistry and molecular biology. Am. J. Clin. Nutr. 1996, 63, 797S-811S. [CrossRef]

9. Linder, M.C. Nutritional biochemistry of copper, with emphasis on the perinatal period. In Biochemical Aspects of Human Nutrition; Avigliano, L.A., Rossi, L., Eds.; Transworld Research Network: Trivandrum, Kerala, India, 2010; pp. 143-179. ISBN 978-81-7895-478-3.

10. Turnlund, J.R.; Keyes, W.R.; Anderson, H.L.; Acord, L.L. Copper absorption in young men at three levels of dietary copper. Am. J. Clin. Nutr. 1989, 49, 870-878. [CrossRef]

11. Hausmann, D.H.; Porstmann, T.; Weber, I.; Hausmann, S.; Dummler, W.; Liebe, S.; Emmrich, J. Cu/Zn-SOD in human pancreatic tissue and pancreatic juice. Int. J. Pancreatol. 1997, 22, 207-213. [CrossRef]

12. Evering, W.E.N.D.; Haywood, S.; Bremner, I.; Wood, A.M.; Trafford, J. The protective role of metallothionein in copper overload: II. Transport and excretion of immunoreactive MT-1 in blood, bile and urine of copper-loaded rats. Chem. Biol. Interact. 1991, 78, 297-305. [CrossRef]

13. Cumings, J.N. Heavy Metals and the Brain; Blackwells Scientific Publications: Oxford, UK, 1959.

14. Weiss, K.C.; Linder, M.C. Copper transport in rats involving a new plasma protein. Am. J. Physiol. Endocrinol. 1985, 249, E77-E88. [CrossRef] [PubMed]

15. Cabrera, A.; Alonzo, E.; Sauble, E.; Chu, Y.L.; Nguyen, D.; Linder, M.C.; Sato, D.S.; Mason, A.Z. Copper binding components of blood plasma and organs and their response to influx of large doses of ${ }^{65} \mathrm{Cu}$, in the mouse. Biometals 2008, 21, 525-543. [CrossRef] [PubMed]

16. Das, S.; Ray, K. Wilson's disease: An update. Nat. Clin. Pract. Neurol. 2006, 2, 482-493. [CrossRef] [PubMed]

17. Shilsky, M.L.; Irani, A.N.; Gorla, G.R.; Volenberg, I.; Gupta, S. Biliary copper excretion capacity in intact animals: Correlation between ATP7B function hepatic mass, and biliary copper excretion. J. Biochem. Mol. Toxicol. 2000, 14, 210-214. [CrossRef]

18. Harada, M.; Sakisaka, S.; Yoshitake, M.; Shakadoh, S.; Gondoh, K.; Sata, M.; Tanikawa, K. Biliary copper excretion in acutely and chronically copper loaded rats. Hepatology 1993, 17, 111-117. [CrossRef] [PubMed] 
19. Lech, T.; Sedlick, J.K. Copper concentration in body tissues and fluids in normal subjects of southern Poland. Biol. Trace Elem. Res. 2007, 118, 10-15. [CrossRef]

20. Lutsenko, S.; Barnes, N.L.; Bartee, M.Y.; Dmitriev, O.Y. Function and regulation of human copper-transporting ATPases. Physiol. Rev. 2007, 87, 1011-1046. [CrossRef]

21. Linz, R.; Barnes, N.L.; Zimnicka, A.M.; Kaplan, J.H.; Eipper, B.; Lutsenko, S. Intracellular targeting of copper-transporting ATPase ATP7A in a normal and Atpb-/- kidney. Am. J. Physiol. Renal Physiol. 2008, 294, F53-F61. [CrossRef]

22. Pierson, H.; Muchenditsi, A.; Kim, B.-E.; Ralle, M.; Zachos, N.; Huster, D.; Lutsenko, S. The function of ATPase copper transporter ATP7B in intestine. Gastroenterology 2018, 154, 168-180. [CrossRef]

23. Middleton, R.B.; Linder, M.C. Synthesis and turnover of ceruloplasmin in rats treated with $17 \beta$-estradiol. Arch. Biochem. Biophys. 1983, 302, 362-368. [CrossRef]

24. Polishchuk, E.V.; Concilli, M.; Iacobacci, S.; Chesi, G.; Pastore, N.; Piccolo, P.; Paladino, S.; Baldantoni, D.; van Ijzendoorn, S.C.; Chan, J.; et al. Wilson disease protein ATP7B utilizes lysosomal exocytosis to maintain copper homeostasis. Dev. Cell 2014, 29, 686-700. [CrossRef]

25. Polishchuk, R.; Lutsenko, S. Golgi in copper homeostasis: A view from the membrane trafficking field. Histochem. Cell Biol. 2013, 140, 285-295. [CrossRef] [PubMed]

26. Polishchuk, R.S.; Polishchuk, E.V. From and to the Golgi-Defining the Wilson disease protein road map. FEBS Lett. 2019, 593, 2341-2350. [CrossRef]

27. Stewart, D.J.; Short, K.K.; Maniaci, B.N.; Burkhead, J.L. COMMD1 and PtdIns $(4,5)$ P2 interaction maintain ATP7B copper transporter trafficking fidelity in HepG2 cells. J. Cell Sci. 2019, 132. [CrossRef]

28. Muller, P.; van Bakel, H.; van de Sluis, B.; Holstege, F.; Wijmenga, C.; Klomp, L.W. Gene expression profiling of liver cells after copper overload in vivo and in vitro reveals new copper-regulated genes. J. Biol. Inorg. Chem. 2007, 12, 495-507. [CrossRef] [PubMed]

29. Van den Berghe, P.V.E.; Klomp, L.W.J. Posttranslational regulation of copper transporters. J. Biol. Inorg. Chem. 2010, 15, 37-46. [CrossRef] [PubMed]

30. Oh, W.J.; Kim, E.K.; Park, S.H.; Hahn, S.H.; Yoo, O.Y. Cloning and characterization of the promoter region of the Wilson disease gene. Biochem. Biophys. Res. Commun. 1999, 259, 206-211. [CrossRef]

31. Bauerly, K.A.; Kelleher, S.L.; Lonnerdal, B. Effects of copper supplementation on copper absorption, tissue distribution, and copper transporter expression in an infant rat model. Am. J. Physiol Gastrointest. Liver. Physiol. 2005, 288, G1007-G1014. [CrossRef]

32. Huang, Y.L.; Ashwell, M.S.; Fry, R.S.; Lloyd, K.E.; Flowers, W.L.; Spears, J.W. Effect of dietary copper amount and source on copper metabolism and oxidative stress of weanling pigs in short-term feeding. J. Animal. Sci. 2015, 93, 2948-2955. [CrossRef]

33. Minghetti, M.; Leaver, M.J.; George, S.G. Multiple Cu-ATPase genes are differentially expressed and transcriptionally regulated by $\mathrm{Cu}$ exposure in sea bream, Sparus aurata. Aquat. Toxicol. 2010, 97, 23-33. [CrossRef]

34. Stalke, A.; Pfister, E.D.; Baumann, U.; Illig, T.; Reischl, E.; Sandbothe, M.; Vajen, B.; Huge, N.; Schlegelberger, B.; von Neuhoff, N.; et al. MTF1 binds to metal-responsive element e within the ATP7B promoter and is a strong candidate in regulating the ATP7B expression. Ann. Human Genet. 2020, 84, 195-200. [CrossRef]

35. Da Silva, E.S.; Abril, S.I.; Zanette, J.; Bianchini, A. Salinity-dependent copper accumulation in the guppy Poecilia vivipara is associated with CTR1 and ATP7B transcriptional regulation. Aquat. Toxicol. 2014, 152, 300-307. [CrossRef]

36. Lenartowicz, M.; Moos, T.; Ogorek, M.; Jensen, T.G.; Moller, L.B. Metal-dependent regulation of ATP7A and ATP7B in fibroblast cultures. Front. Mol. Neurosci. 2016, 9, 68. [CrossRef]

37. Ravia, J.J.; Stephen, R.M.; Ghishan, F.K.; Collins, J.F. Menkes copper ATPase (Atp7b) is a novel metal-responsive gene in rat duodenum, and immunoreactive protein is present on brush-border and basolateral membrane domains. J. Biol. Chem. 2005, 280, 36221-36227. [CrossRef]

38. Chun, H.; Catterton, T.; Kim, H.; Lee, J.; Kim, B.-E. Organ specific regulation of ATP7A abundance is coordinated with systemic copper homeostasis. Sci. Rep. 2017, 7, 12001. [CrossRef]

39. De Bie, P.; van de Sluis, B.; Burstein, E.; van der Berghe, P.; Muller, P.; Berger, R.; Gitlin, J.D.; Wijmenga, C.; Klomp, L.W.J. Distinct Wilson-disease mutations in ATP7B are associated with enhanced binding to COMMD1 and reduced stability of ATP7B. Gastroenterology 2007, 133, 1316-1326. [CrossRef] 
40. Materia, S.; Cater, M.A.; Klomp, L.W.J.; Mercer, J.F.B.; La Fontaine, S. Clusterin (apolipoprotein J), a molecular chaperone that facilitates degradation of the copper ATPases ATP7A and ATP7B. J. Biol. Chem. 2011, 286, 10073-10083. [CrossRef]

41. Materia, S.; Cater, M.A.; Klomp, L.W.J.; Mercer, J.F.B.; La Fontaine, S. Clusterin and CommD1 independently regulate degradation of the mammalian copper ATPases ATP7A and ATP7B. J. Biol. Chem. 2012, 287, 2485-2499. [CrossRef]

42. Hatori, Y.; Lutsenko, S. the role of copper chaperone Atox1 in coupling redox homeostasis to intracellular copper distribution. Antioxidants 2016, 5, 25. [CrossRef]

43. Frommer, D.J. Biliary copper excretion in man and the rat. Digestion 1977, 15, 390-396. [CrossRef]

44. Martin, M.T.; Jacobs, F.A.; Brushmiller, J.G. Low molecular weight copper-binding ligands in human bile. Proc. Soc. Exp. Biol. Med. 1986, 181, 249-255. [CrossRef]

45. Iyengar, V.; Brewer, G.J.; Dick, R.D.; Owyang, C. Studies of cholecystokinin-stimulated biliary secretions reveal a high molecular weight copper-binding substance in normal subjects that is absent in patients with Wilson's disease. J. Lab. Clin. Med. 1988, 111, 267-274. [PubMed]

46. Samuels, A.R.; Freedman, J.H.; Bhargave, M.M. Purification and characterization of a novel abundant protein in rat bile that binds azo dye metabolites and copper. Biochim. Biophys. Acta 1983, 759, 23-31. [CrossRef]

47. Kressner, M.S.; Stockert, R.J.; Morell, A.G.; Sternlieb, I. Origins of biliary copper. Hepatology 1984, 4, 867-870. [CrossRef]

48. Van den Hammer, C.J.A.; Morell, A.G.; Scheinberg, I.H. Physical and chemical studies on ceruloplasmin. IX. The role of galactosyl receptors in clearance of ceruloplasmin from the circulation. J. Biol. Chem. 1970, 245, 4397-4402.

49. Morell, A.G.; Irvine, R.A.; Sternlieb, I.; Scheinberg, I.H.; Ashwell, G. Physical and chemical studies on ceruloplasmin. V. Metabolic studies on sialic acid-free ceruloplasmin in vivo. J. Biol. Chem. 1968, 243, 155-159.

50. Tavassoli, M. Liver endothelium binds, transports, and desialates ceruloplasmin which is then recognized by galactosyl receptors of hepatocytes. Trans. Assoc. Am. Phys. 1985, 98, 370-377.

51. Hauser-Davis, R.A.; Goncalves, R.A.; Ziolli, R.L.; de Campos, R.C. A novel report of metallothionein in fish bile: SDS-PAGE analysis, spectrophotometry quantification and metal speciation characterization by liquid chromatography coupled to ICP-MS. Aquat. Toxicol. 2012, 116, 54-60. [CrossRef]

52. Land, S.N.; Rocha, R.C.C.; Bordon, I.C.; Saint Pierre, T.; Ziolli, R.L.; Hauser-Davis, R.A. Biliary and hepatic metallothionein, metals and trace elements in environmentally exposed neutropical cichlids Geophagus brasiliensis. J. Trace Elem. Med. Biol. 2018, 50, 347-355. [CrossRef] [PubMed]

53. Ramos, D.; Mar, D.; Ishida, M.; Vargas, R.; Gaite, M.; Montgomery, A.; Linder, M.C. Direct uptake of copper from blood plasma ceruloplasmin by mammalian cells. PLoS ONE 2016, 11, e0149516. [CrossRef] [PubMed]

54. Piperno, A.; Alessio, M. Aceruloplasminemia: Waiting for an efficient therapy. Front. Neurosci. 2018, 12, 903. [CrossRef] [PubMed]

55. Kenawi, M.; Rouger, E.; Island, M.L.; Leroyer, P.; Robin, F.; Remy, S.; Tesson, L.; Anegon, I.; May, K.; Derbre, F.; et al. Ceruloplasmin deficiency does not induce macrophagic iron overload: Lessons from a new rat model of hereditary aceruloplasminemia. FASEB J. 2019, fj201901106R. [CrossRef] [PubMed]

56. Meyer, L.A.; Durley, A.P.; Prohaska, J.R.; Harris, Z.L. Copper transport and metabolism are normal in aceruloplasminemic mice. J. Biol. Chem. 2001, 276, 36857-36861. [CrossRef]

57. Chu, Y.-L.; Sauble, E.N.; Cabrera, A.; Roth, A.; Ackland, M.L.; Mercer, J.F.B.; Linder, M.C. Lack of ceruloplasmin expression alters aspects of copper transport to the fetus and newborn, as determined in mice. Biometals 2012, 25, 373-382. [CrossRef]

58. Ke, B.X.; Llanos, R.M.; Wright, M.; Deal, Y.; Mercer, J.F. Alteration of copper physiology in mice overexpressing the human Menkes protein ATP7A. Am. J. Physiol. Regul. Integr. Comp. Physiol. 2006, 290, R1460-R1467. [CrossRef]

59. Wadwa, J.; Chu, Y.-H.; Ngyyen, N.; Henson, T.; Figueroa, A.; Llanos, A.; Ackland, M.L.; Mercer, J.F.B.; Fullriede, H.; Brennan, G.; et al. Effects of ATP7A overexpression on copper transport and metabolism in lactation and gestation, as measured in transgenic mice. Physiol. Rep. 2014, 2, e00195. [CrossRef]

60. Yatsunyk, L.A.; Rosenzweig, A.C. Cu(I) binding and transfer by the $\mathrm{N}$ terminus of the Wilson disease protein. J. Biol. Chem. 2007, 282, 8622-8631. [CrossRef] 
61. Masuoka, J.; Hegenauer, J.; Van Dyke, G.R.; Saltman, P. Intrinsic stoichiometric equilibrium constants for the binding of zinc (II) and copper (II) to the high affinity site of serum albumin. J. Biol. Chem. 1993, 268, 21533-21537.

62. Liu, N.M.; Lo, L.S.L.; Askary, H.; Jones, L.T.; Goforth, J.; Kidane, T.Z.; Vivas, E.; Sebastian, S.; Efron, A.; Tsai, M.T.; et al. Transcuprein is a macroglobulin regulated by copper availability. J. Nutr. Biochem. 2007, 18, 597-608. [CrossRef]

63. Samimi, G.; Safael, R.; Katano, K.; Holzer, A.K.; Tomioka, M.; Goodman, M.; Howell, S.B. Increased expression of the copper efflux transporter ATP7A mediates resistance to cisplatin, carboplatin, oxaloplatin in ovarian cancer cells. Clin. Cancer Res. 2004, 10, 4661-4669. [CrossRef]

64. Mariniello, M.; Petruzzelli, R.; Wanderlingh, L.G.; La Montagna, R.; Carissimo, A.; Pane, F.; Amoresano, A.; Ilyechova, E.Y.; Galagudza, M.M.; Catalano, F.; et al. Synthetic lethality screening identifies FDA-approved drugs that overcome ATP7B-mediated tolerance of tumor cells to cisplatin. Cancers 2020, 12, 608. [CrossRef]

65. Ishida, S.; Lee, J.; Thiele, D.J.; Herskowitz, I. Uptake of the anticancer drug cisplatin mediated by the copper transporter Ctr1 in yeast and mammals. Proc. Natl. Acad. Sci. USA 2002, 99, 14298-14302. [CrossRef] [PubMed]

66. Lee, Y.Y.; Choi, C.H.; Do, I.G.; Song, S.Y.; Lee, W.; Park, H.S.; Song, T.J.; Kim, M.K.; Kim, T.J.; Lee, J.W.; et al. Prognostic value of the copper transporters, CTR1 and CTR2, in patients with ovarian carcinoma receiving platinum-based chemotherapy. Gynecol. Oncol. 2011, 122, 361-365. [CrossRef] [PubMed]

67. Linder, M.C. Ceruloplasmin and other copper binding components of blood plasma and their functions: An update. Metallomics 2016, 8, 887-905. [CrossRef] [PubMed]

68. Kidane, T.Z.; Farhad, R.; Cabrera, A.; Roth, A.; Ackland, M.L.; Mercer, J.F.B.; Linder, M.C. Uptake of copper from plasma proteins in cells where expression of CTR1 has been modulated. Biometals 2012, 25, 697-709. [CrossRef]

69. Moriya, M.; Ho, Y.-H.; Grana, A.; Nguyen, L.; Alvarez, A.; Jamil, R.; Ackland, M.L.; Michalczyk, A.; Hamer, P.; Ramos, D.; et al. Copper is taken up efficiently from albumin and a2-macroglobulin by cultured human cells by more than one mechanism. Am. J. Physiol. Cell Physiol. 2008, 295, C708-C721. [CrossRef]

70. George, T.; Hoonmurthy, J.B.; Shiashankara, A.R.; Suresh, S.; Baliga, M.S. Correlation of blood and salivary levels of zinc, iron and copper in head and neck cancer patients: An investigative study. Avicenna J. Med. Biochem. 2017, 5, 35-39. [CrossRef]

71. Faraz, M.; Manohar, V.; D'Souza, N. Estimation of copper in saliva and areca nut products and its correlation with histological grades of oral submucous fibrosis. J. Oral Pathol. Med. 2015, 44, 208-213. [CrossRef]

72. Hong, J.H.; Duncan, S.E.; Dietrich, A.M.; O'Keefe, S.F.; Eigel, W.N. Interaction of copper and human salivary proteins. J. Agric. Food Chem. 2009, 57, 6967-6975. [CrossRef]

73. Robinson, R.; Kauffman, D.L.; Waye, M.M.Y.; Blum, M.; Bennick, A.; Keller, P.J. Primary structure and possible origin of the non-glycosylated basic proline-rich protein of human submandibular/sublingual saliva. Biochem. J. 1989, 263, 497-503. [CrossRef]

74. Conklin, S.E.; Bridgman, E.C.; Su, Q.; Riggs-Gelasco, P.; Haas, K.L.; Franz, K.J. Specific histidine residues confer histatin peptides with copper-dependent activity against Candida albicans. Biochemistry 2017, 56, 4244-4255. [CrossRef] [PubMed]

75. Blotnick, E.; Sol, A.; Bachrach, G.; Muhlrad, A. Interaction of histatin-3 and histatin-5 with actin. BMC Biochem. 2017, 18, 1-13. [CrossRef] [PubMed]

76. Sun, X.; Salih, E.; Oppenheim, F.G.; Helmerhorst, E.J. Kinetics of histatin proteolysis in whole saliva and the effect on bioactive domains with metal-binding, antifungal, and wound-healing properties. FASEB J. 2009, 23, 2691-2701. [CrossRef] [PubMed]

77. Moffa, E.B.; Machado, M.A.A.M.; Mussi, M.C.M.; Xiao, Y.; Garrido, S.S.; Giampaolo, E.T.; Siqueira, W.L. In vitro identification of histatin 5 salivary complexes. PLoS ONE 2015, 10, e0142517. [CrossRef] [PubMed]

78. Owen, C.A., Jr. Physiological Aspects of Copper: Copper in Organs and Systems; Noyes Publications: Park Ridge, IL, USA, 1982.

79. Powell, J.J.; Greenfield, S.M.; Thompson, R.P.H. Concentrations of metals in gastric juice in health and peptic ulcer disease. Gut 1992, 33, 1617-1620. [CrossRef]

80. Miyata, S.; Toyoshima, M.; Takashima, M.; Itokawa, Y. Metal contents in duodenal aspirates of normal subjects during pancreozymin-secretin test. Gastroenterol. Jpn. 1982, 17, 207-213. [CrossRef] 
81. Carrigan, P.E.; Hentz, J.G.; Gordon, G.; Morgan, J.L.; Raimondo, M.; Anbar, A.D.; Miller, L.J. Distinctive heavy metal composition of pancreatic juice in patients with pancreatic carcinoma. Cancer Epidemiol. Biomark. Prev. 2007, 16, 2656-2663. [CrossRef]

82. Ishihara, N.; Yoshida, A.; Koizumi, M. Distinctive metal compositioin of human pancreatic juice in patients with pancreatic carcinoma. Arch. Environ. Health 1987, 42, 356-360. [CrossRef]

83. Heacox, H.N.; Gillman, P.L.; Zwart, S.R.; Smith, S.M. Excretion of zinc and copper increases in men during 3 weeks of bed rest, with and without artificial gravity. J. Nutr. 2017, 147, 1113-1120. [CrossRef]

84. Ishihara, N.; Matsushiro, T. Biliary and urinary excretion of metals in humans. Arch. Environ. Health 1986, 41, 324-330. [CrossRef]

85. Ranjkesh, F.; Jaliseh, H.K.; Abutorabi, S. Monitoring the copper content of serum and urine in pregnancies complicated by preeclampsia. Biol. Trace Elem. Res. 2011, 144, 58-62. [CrossRef] [PubMed]

86. Grimes, A.; Hearn, C.J.; Lockhart, P.; Newgreen, D.F.; Mercer, J.F.B. Molecular basis of the brindled mouse mutant (Mobr): A murine model of Menkes disease. Hum. Mol. Genet. 1997, 6, 1037-1042. [CrossRef] [PubMed]

87. Moore, S.D.P.; Cox, D.W. Expression in mouse kidney $\mathrm{f}$ membrane copper transporters Atp7a and Atp7b. Nephron 2002, 92, 629-634. [CrossRef] [PubMed]

88. Barnes, N.; Bartee, M.Y.; Braiterman, L.; Gupta, A.; Ustiyan, V.; Zuzel, V.; Kaplan, J.H.; Hubbard, A.L.; Lutsenko, S. Cell-specific trafficking suggests a new role for renal ATP7B in the intracellular copper storage. Traffic 2009, 10, 767-779. [CrossRef] [PubMed]

89. Suzuki, Y.; Toda, K.; Koike, S.; Yoshikawa, H. Cadmium, copper and zinc in the urine of welders using cadmium-containing silver solder. Ind. Health 1981, 19, 223-230. [CrossRef] [PubMed]

90. Suzuki, Y.; Yoshikawa, H. Cadmium, copper, and zinc excretion and their binding to metallothionein in urine of cadmium-exposed rats. J. Toxicol. Environ. Health 1981, 8, 479-487. [CrossRef]

91. Squitti, R.; Ventriglia, M.; Barbati, G.; Cassetta, E.; Ferreri, F.; Dal Forno, G.; Ramires, S.; Zappasodi, F.; Rossini, P.M. "Free" copper in serum of Alzheimer's disease patients correlates with markers of liver function. J. Neural. Transm. 2007, 114, 1589-1594. [CrossRef]

92. Walshe, J.M. The pattern of urinary copper excretion and its response to treatment in patients with Wilson's disease. Q. J. Med. 2011, 104, 775-778. [CrossRef]

93. Gray, L.W.; Peng, F.; Molloy, S.A.; Pendyala, V.S.; Muchenditsi, A.; Muzik, O.; Lee, J.; Kaplan, J.; Lutsenko, S. Urinary copper elevation in a mouse model of Wilson's disease is a regulated process to specifically decrease the hepatic copper load. PLoS ONE 2012, 7, e38327. [CrossRef]

94. Huster, D.; Finegold, M.J.; Morgan, C.T.; Burkhard, J.L.; Nixon, R.; Vanderwerf, S.M.; Gilliam, C.T.; Lutsenko, S. Consequences of copper accumulation in the livers of Atp7b-/- (Wilson Disease gene) knockout mice. Am. J. Path. 2006, 168, 423-434. [CrossRef]

95. Squitti, R.; Siotto, M.; Cassetta, E.; El Idrissi, I.G.; Colabufo, N.A. Measurement of serum non-ceruloplasmin copper by direct fluorescent method specific to Cu (II). Clin. Chem. Lab. Med. 2017, 55, 1360-1367. [CrossRef] [PubMed]

(C) 2020 by the author. Licensee MDPI, Basel, Switzerland. This article is an open access article distributed under the terms and conditions of the Creative Commons Attribution (CC BY) license (http://creativecommons.org/licenses/by/4.0/). 